University of Rhode Island

DigitalCommons@URI

Open Access Master's Theses

1963

\title{
American Alliance Policy in Southern Asia: 1953-54
}

Prakash Chandra Kapil

University of Rhode Island

Follow this and additional works at: https://digitalcommons.uri.edu/theses

\section{Recommended Citation}

Kapil, Prakash Chandra, "American Alliance Policy in Southern Asia: 1953-54" (1963). Open Access

Master's Theses. Paper 1790.

https://digitalcommons.uri.edu/theses/1790

This Thesis is brought to you for free and open access by DigitalCommons@URI. It has been accepted for inclusion in Open Access Master's Theses by an authorized administrator of DigitalCommons@URI. For more information, please contact digitalcommons-group@uri.edu. 
DS518.8

AMERICAN ALLIANCE POLICY IN SOUTHEKN ASIA:

$1953-54$

BY

PRAKGASH CHANDRA KAPIL

A THESIS SUBUITTED IN PARTIAL FULFILLAENT OF THE REQUIREMENTS FOR THE DEGREE OF MASTER OF ARTS

IN

INTERNATIONAL RELATIOHS

UNIVERSITY OF RHODE ISLAND

1968 


\section{MUSTRACI}

Lirect Americun interest in Southern \&sia began only after the Becond World War as a result of three confluencing events which entirely changed the westem-orientea power pattern in the whole of Asta.

One of these events was the demission in a short period of the Imperial West from all of 1 ts more important colonial outposts in asia. Against a baciground of centuries of explottation and humilation, this parting bade falr to be permanent: i.e., any Western return in the old style had become impossible in the forseeable ruture.

27 The secona event was of more direct concern to $t$ is $e$ United states. Before and during the Second Har her strategy in Asia was contred around Japan and China, the former as a threat to be tamed and the latter as her vard and future hope, promising a vast potentiai for investments, trade, and cultural and relifious activities. With Chiang Kai-shek's defeat by Comanist forces in 1949 all this changed, crusing à wave of outcry by certain political forces to an axtent rarely paralleled in American history. The subsequent Fed Chlnese intervention in the korean war forced the United states government into an "kgonfsing reappraisal" of its policies in the Orient.

The third event which wes destined to count so much in Southern Asfa, but vinich the Right Irig "Asialationists" were mentally unprepared to accept, was the emergence of nhat has 
been called "neutralism" in some of the key countries of the region.

Ali these trends had become clear by l95i. What was the rection of the United states to these trends? How did she set abcut reorienting her attitudes and policies during the yeurs of readjustment?

These questions have been studied in four-atmensional context: i) the changing international setting; 2$)$ the place of Southern Asia in American international and domestic pol1cies; 3) the actual formulation of U.S. polieles in this area and the manner of their execution; ard, 4) the effects of United states sctions on her relations 1 th the countries of the region and on the relations of trese countries amona themselves.

whlle history cannot be ignored in stadying a historical period, the approach adopted in this study is topical a $\mathrm{n}$ analytical rather than chronological. Although reference has been made to precedin and succeedne events for tho purpose of providing a perspective, the study's focus has been on the flrst two years of the Hisenhoner foninistration.

whe research finings of this study inaicate that Unlted States policies towards southern Bsia during 1958 ard 195* were baseo on outdated and internelly luconsistert postulates. They produced "solutions" which vere related neither to the international issues of the time nor to the sctual problems of the area. As a consecience, they tended to be inefíctive and self-cefeating. 
CONFENTS

PAGES

ABSTRACT . . . . . . . . . . . . . . .11-1i1

PREACB .......................... v1-r11

I. INTRODUCHION , ........, , ... 1-15

The Geographical Region, i) Its International

Importance, 2; U.S. and Southern Asia in the

Colonial Past, 4; A Tryst W1th Dest1ny, 7;

Regional Realities, $9 ;$ American Response to

Changing $\mathrm{H}$ ia, 12 .

I. THE OLD AND THE "NET LOOK" AND SOUTHERN ASIA . 16-37

1947-51: Containment in Europe, 17; Korean

War and Containment in As1a, 18; 1952-54:

A "Nev Look" Energes, 22; Challenge and

Response, 32

III. A gRrategg of alienation . . . . . . . 38-53

Nehru Loses U.8. Favor, 3a; The Political

Cost, 41; India Deflected From Concern

with China, 44; Pakistan As An Ally, 45; The

Long, Tangled Background, 47.

IV. SEATO: THE INVERTED MOLLBACK" . . . . . 54-74

Indochina: The French "Country", 54; The 'Him

of Helli Thesis, 57; Who W111 be"gaved, 60;

Economic and Soclal Matters, 64; Military

Efficacy of Seato, 64; USA: The Kingpin of

Seato, 69; seato in Action, 70; Subversion,

Seato's Hightmare, 71 .

. COMCLUSIOHS ............ 75-84 BIBLIOGRAPHY .................. 85-89

SOUTHERN ASIA AND NEIGHBORS (MAP) .......... vil1 


\section{PREFACE}

The idea of this study developed from a research paper on the Southeast Asia Treaty Organisation which I wrote earlier for Professor David D. Warren. Most of the writers on Seato I happened to read tended to examine it mainly in terms of the Treaty which created it. This approach seemed to me to be only partially satisfactory. It left one cruclal question unanswered: Why would such a powerful nation as the United states mant to associate herself with a proposition which, at its best, succeecea only in attracting nations whose particularist aims scarcely coincided with her own, and wich, at its worst, seemed to have resulted in alienating a large segment of the Asian sentiment? I found little help from official authors from Seato countries who generally offered facile deferse from thelr position of prior commitment. Similarly, spokesmen for the non-ineider istan governments mpearea to react emotionaliy to what they had already rejected in fact.

It was bacause of this intellectual dissatisfaction that I decided to enlarge the periscope to include the overall domestic and international context from which American decisionmakers at that tIme woula have looked at Southern Asia. In this approach seato becomes only one expression of a manyfaceted policy matrix. It is hoped that my effort will help explain this phase of U.S. policies more clearly.

didy debts are many, and not always icientifiable. Ine members of the Thesis Comattee naturally have ihe firat clain. Hovever, Professor Robert F. Suith is perticularly entitled 
to my gratitude. To ism I owe a huge intellectual debt. It is my pleasure to acmowledge the understanding and help I received frof Dr. George Goowir, Chaiman of the Department of Political science and Dear Erast w. Hertung of the Graduate bchool. Without the unlimited coopertion and oispatch nith which Professor Francis flien and otiler members of the University uibrary helpea me in obtainirg materials f $r$ o m elsewhere this hora could not have beer completed hithin the time at my oisposal.

When I so bach to my country I shall al ays look back on my stay at the Univerity of Rhoie Islaro with the fondest memories.

Hay $\because-1063$ P.C.X. 


\section{INTRODUCIION}

\section{The Geograghic Region}

This study will examine the post-Korean war phase of United States relations with the mainland and island countries constituting the great Asian arc from ffghanistan in the Northwest to the Philippines in the Southeast.

Unhappliy, a terminology acceptable to all to describe the area has yet to be found. The phrase 'South and Southesst Asia' has gained wide currency during recent years, thanks largely to the hmerlcan university circles and their area study programs. Nevertheless, these terms have meant different things to the historlan, geographer, and geopolitician.

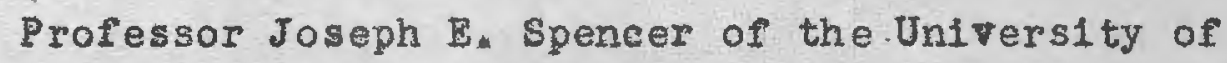
California, Los Angelos, used the expression "Asla, South by East". The U.S. State Department Geographer, Mr. G. Etzel Pearcy employs the phonetically monstrous variation: "Geographic Regions of Asta: South and East". Dr. Russel H. Fifleld, a political sclentist, in the current fashion among acadenic writers, favors the dichotomous "South Asia" and "Southeast Asia" as the "political area" classification. The Chinese refer to 'Southeast Asla' as Nanyang (11terally, "South Ocean"i). The Japanese use the same term, but pronounce it Nanyo. The Australians look at it as "Near North", and the Indans favor a more endearing term, "Further 
India", citing their substantial historical and cultural ties with the area.

Afghanistan is considered by many, as also vest Paristan by some for some purposes, to have greater affinity with the area varlously described as Midde East, Neir East, or Central Asia. Ceylon is included by some with Inliz in "South Asia" and in "Soltheast Asia" by others. The Philippines tends to be placed in "Southeast Asia" by Americans but not by the British.

To avoic all this multiple verbiage and to steer clear of the nationalistic preference, for our purpose we shall adopt the generlc term, "Southern Asial, after Professor Charles Wolf,Jr. 2 , to denote the entire area from Afghanistan to the Philippines including the Indo-Pacific oceanic island countries on the way.

\section{Its International Importance}

Afghanistin, the two parts of Paiststan (East and Vest), Indla, Nepel, Bikxim, Bhutan, Ceylon, Burma, Thalland, Cambodia, Laos, the tro Vietnams (North and South), Ralaya, the Indonesian archipelago, and the Philipplnes: these fourteen countries have an area of about 3.5 millon square miles and a population of over 675 million. Culturally and ethnically,

1. There will, however, be occasions when we will have to refar separately to the Philippines, Indonesia, Thailind, Viet-ram, Lisos, Cambodia, ifalaya and Burma as a grouping. we will then use the collective term "Southeast Asla".

E. Foreign Aid: Theory and Practice in Sojthern Asta 
the region exhibits a puzzing array of diverse strands. Its three hunored spoiren languages and the presence bithin it of nearly every religion of the morla--Fuanism, Christianity, Hinduism, Islam, Lorastrianism, and some unique syrtheses like Cao Dai and Hao Haom-illustrate the point. Yet, there is enough of a communty of shared past and of present problems and sspirations that lends this 'free arc of homogeneity and character.

Together, these countries supply more than 90 percent of the horld's rubber, tea, and fute and over 85 percent of Its rice. The west's substantial dependence on this area's tremendous output of such essentisl industrial raw materials as tir, mica, manganese, iron ore, chrome ore, and tungster is acinowledged. Its potential as a market for the goods of the more inautrialised nations is dependent on its on economic betterment but has already been and must remain a big consideration in their thining of this reaion.

Lying as it does astride the min sea, land, and air routes connecting Europe with the Pacific through the 活idile East, its strategic importance is weli understood. The region's

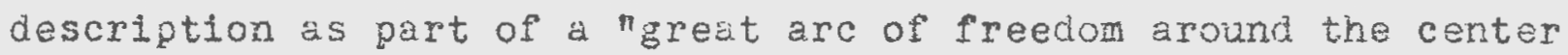
of Communist poner in Asia" 3 is a recent American feather in its cap.

3. Mtuäl Becurity Program, Fiscul Year 1956: A Summary Statement (Viashingtor: Foreign Operations Áloinistration,

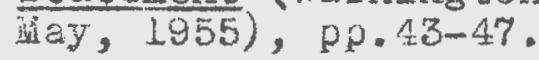


U.S. and Southern isia

In Colonial past

Up to the tine of ner participation in the First world of the United States

War the traditional policy/vis-a-vis the Europear Impertal

Powers has been aptly sumed up in Alfred Thager Muhan's

famous triology: "In America: Predominance", "In Europe: sbstention", and "In Asia: Cooperation".

"Cooperation" in asia nas epitomized in the celebrated "Open Door" policy which, to use s metaphor, has essentially "polyandrous" ir conception: the basic idea being thet everyboay should have equal access to a territory. It fell to Cuina to be the proving ground for this "cooperution", and it was primarily China's great mysticki, manetic pull wich had made the United States "potentially a Pacific pover since 1805, actually since 1846, emphatically after 1867"4, verily since 1898 and unquestionably aiter world War II.

Chiria's charm in fact never bloomed into a vast open market, nor did the Chinese charge into a "civilized, Christion" people. Its teening million nonetheiess never lost the attraction anc always remined an irreaistible future hope till

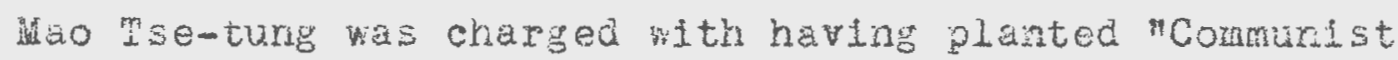
witches" in the State Departiont who "handed oyer" the China apple to him.

Although there were easlier sporadic forays, America's

4. Samuel Flagg Benis, A Bhort History of Americh Forelign Policy and Diplomacy (New York: Rinehart, 1953), p.297. Professor Bemis' famous evaluation of the Philiopines acquisition as "the great aberration" would seem to be inconsistent wh this statement. 
planned entree into the Pacific and China becume possible only wth the wresting of the Philippines from Epain in 1338. To safezuard this evant garde of 'manifest destiny' in the Pacific, the united States had to build a costly soldernet of navil bases, fuel stations, ana commucations. A first-rate navi base vids built at Pezrl Harbor and fortification of Guam, Wake Island, Midway was inltiated at the begining of the Second World war.

With the British, the Lutch, the French, the Portiguese and the Germans firmly entrenched in wost of Southern Asia, Australia and New Zealand, the Americans had neitier the chance to look west- and southwarc of the Philippines for expunion, nor, consecuently, the necessity for building defenses against these flanks, thanirs to the policy of "cooperation". Her main challenger arose from ráther unexpected quarters, the Oriental parvenu Japan.

Before ard for some time during the Russo-Japanese War of 1905, Theociore Roosevelt hac acopted an attitude of encouraging the Niponese as a counter to Fussia's designs In the Fur iast. But, thereater, Japan's groping strersth ano aggresigue eye on the "open door" in China caised a sort of andeclared "cold mar" $x$ th the Unfed states, and, in time, the two became the chief contenders in the Paciflc. Eventusily, only the American might in the Pactfic came to be check on $\mathrm{J}$ ean's anbitions of a "Greater Asia" or the "Asian CoFrosperity Suhere".

The mesning of the 5:5: 5 ratio of naval strergth 
prescribed by the ashirgton ireaty after the First horld war, combined with the strategic triangular hoid of AngloAmerican forces in Kong Kong, Hanila, and Sirigapore, was not lost on the Japanese. T. S. Jepurese reliztons propessively deteriorsted thereafter and culminata fr total hostiilties during the Seconc horld iar ard an equally total defeat for Jepan.

Thus at the end of the Second war the United states emerged supreme in the Pacific. Japar lay prostrate ard the War had left the other Poners in no position to challenge the U.S. position. But with this suprenecy came other and more menaclug challenges which were boon to involve the United States on a world-wice scale and in areas which rad been of so little concern to her thus far.

As this raold survey shons the United states had been prinaxily concerned wth Japar and China in the Pacific, abeit in a feprent wys. Ler comectons with the countries in Southern \&sis were sperng. She depented on the Britisi anc other "friendiy" posers for the protectiu of lier ainor

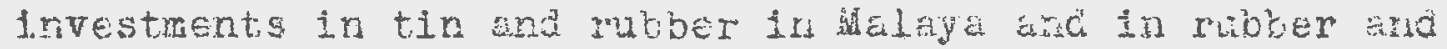
petrolecm ir Irdoresta and her otrer negligible interests in

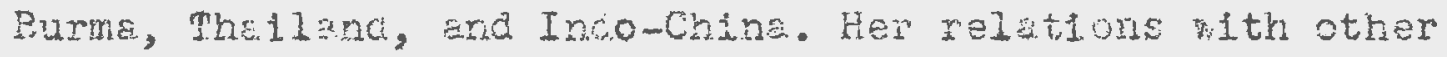
countries of the area including India pere minly cultural and on a private plans through Christian wiscionwies and educetionists. By witherafne from tre philipgines sre had ade

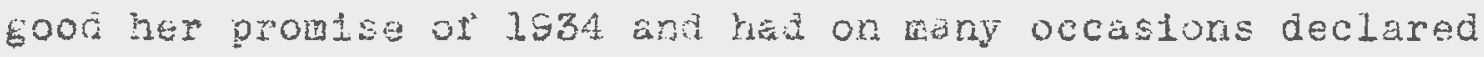
her sympthy for freecom from coloni tule in other countries 
of the area, for which they were grateful.

But within half" a decade after the lar the entire

scerie was transformed and the linited states becane the most potert factor in the hole of southern Asta.

\section{A Tryst With Destiny}

Most of the factors wich provide the present setting in Southern Asia belong to recent kistory, so that an enumeration here is fustified only because of their very great bearing on a proper understanding of the evolving dmerican response to that region's problems.

The most outstandinf fact on the ent1re soutrern Asian scene is that of change; change from a centuries-old social, political and economic stagnation which in the west has understandably been termed as the "revolt of Asia".

All of these countries with the exception of Thaflund and Afghanistan had beenunder foreign domination of one sort or other. They had been charing under this yoze and in most countries national movements were takine militant character. These national struggles had grown out of genuine patriotism and local grievances of racial discrimination./econonic and political exploitation. In many respects people were inferior in thelr own country. Decisions vitally affecting them used to be made in about half a dozen forelgn capitals.

The western ideas of liberty, equility, and fraterity and of constitutional government had much to do with the thinking of the national leaders. In addition, the success of 
the Comanist Revolution in Russia ${ }^{5}$, raidy changing the face of that agrarian country in open defiance or the West and despite its animosity, acted as a great Insplrational force. During the war, the Japenese occupation of rost of the Southeastern segment of this region had given its people a certain taste of independence, hovever. fictitious their participation in the national administrations might have been.

The surprising ease wth wich these areas fell to Jupan and tre wiling cooperation she recelved in many places pointed up, as nothins else had done before, $t h$ e impossibility of defenaing a territory in the absence of locil enthusiasm. It also showed that the industrial base for modern defense cannot exist in an economy orderea srimarily ex-hypothesi, on the "development" basis.

All these factors resulted in an avalanche which by 1950 swept the Imperial Powers out of most of Southern Asia, except Malaya winfch finally became independert in 1957 . The three Indo-Chinese states of Vietnam, Laos, anc Canbodia lagged. behina.The French, under constant pressure of events and Hmerican insistence, did give formal recognition to "ufuly independent and sovereign state of Vietnam" in 19546--the

5. Whatever happens in Russia has al bays exerted powerful iniuence on the nelghboring For the impact of the non-Communtst Revolution of 1905 see

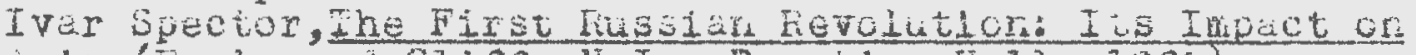

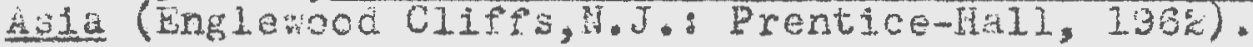
6. Ho sepurate treaties were simultaneousiy sisnea, trie second of "associetion" with the french Union. The treaties were never technicaily put into force. 
13at of these states to be so recogaised-but still continue to be tiere under special treaties of "association". Tho toneral poverty ani ilittersey of the entire arsat ary to the colonial past, and "the revolution of

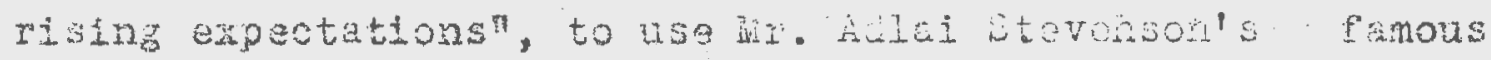
euphemisa, are factors which must wejgh in any toreign relations calculus of these countries.

linother factor of vory great importencs, which is rather a by-product of the other factors mentioned above, is the latenaty of feeling vith which the mases of the people look upon their newiy won freedom and on foreign intentions In anytusar sonesming tivein countries. It way be nothing more than he proverbid once-bitten-twice-shy attitude; but it is trere and ary westem paternis sm, hovever well-meandng, is fudged accoraingly, whstever the ruling elites in certin countries may or may rot do.

\section{Eegional Fiejlities}

During the bygone colonial days the relations between the countries of the region underwent a metamorphosis. Nextdoor neighbors are shut off from each other and whatever Litle intra-regianal intercourse existed had to be "permitted" by the possessing foreign poyer in each country.

All this was bound to change after indepenaence, s\$ illustrated by the increasingy closer consultations anong tre so-called Astan neutrals who heve kept ciear of poreign entanglements. There is no denying the fact that fifirianistan, 
Bhutan, Burma, Ceylon, India, Indonesia, Cambodia, Laos, piaya, Nepul, and slkkim--eleven of the fourteen countries of the region-have a certain identity of outioos on thelr extermi reistions. weit to themeoves, perhes phatuand

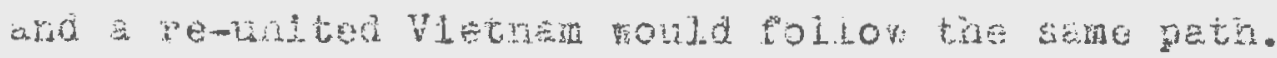

In the ewomid sphore, ant of the conntries have pre-indistrial infra-structuras and mutuliy conpetitive agricultarai aconomies. Bnt as davelopant takes plecs, their complentarity is sure to increase. As it is, India, being relatively more alvarced in indistrialigation, has already been helging sone of these countries ath tochrical snow-how and, in fow fases, even with capital joods. pakistun has a surplus of raw jute and long-stegle cotton which Inda's ralis can ard do ahsorb. Burma's surplus rice can be rofioneily ased. To mention only a fer exangles.

In any geo-ptratogy of the ares Irinda must ocoupy a central position. Bingspore at the hese of the rutural gatery ot the strit of Malace and the thinge formea by

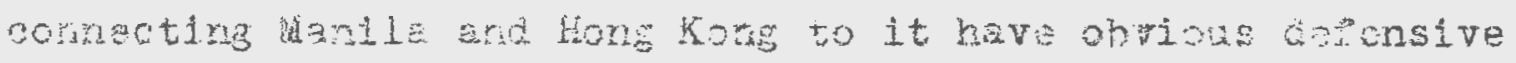
value in the rypothatical event of a sea attack on the area rrom the preific. Indonstia too promises to nare formijable

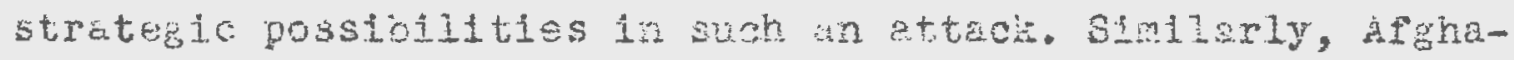
nistan, in the Morthwest and Burma, Vietnem, Laos, and Sikkim,

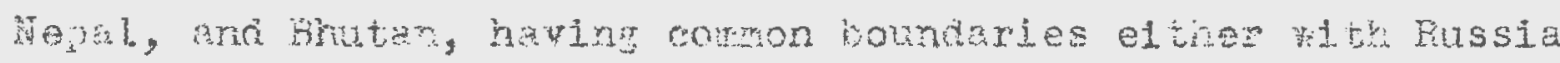
or Crina, wili have to provide first-line defones. But India, with her iong arching sez oost, end tro thougero miles of 
common border ith Communt Chine, will eventually have to bear the min brunt of any large-scale conventional-type Invasion in which not only the holding capacity but the long-term sustaining power would be required.

Her very location, size, resources and the quality of her leadership, to mention only s fev aspects, have placed India in a position which, honest disclaimers to area leadership by Indian politicians notilthstanding, is bound to exert its weight on anything happening in any part of Southern Asia. We mey not accept Professor Hichel Brecher's judgement that her neighbors are "by comparison pymies"7 and ve may not go along with Nehru's self-evaluation:

One of the major questions of the day is the readjustment of relations betveen Asia and Europe. When we talk of Asia, remember that India, not because of any ambition of hers, but because of history, and because of so many other things, inevitably has to play a very important part in Asia. And not only that; Inda becomes a kind of meeting ground for various trends and forces and a meeting ground between what might roughly be cslled the East and west.

Look at the map. If you have to consider ary question affectin the ifidole Bast, Inda inevitably comes into the picture. If you have to consider any cuestion concerning South-East Asia, you cannot do so vithout India. So also with the Far Bast. While the dijdie East may not be directly connected with South-iast Asia, both are connected sth Ind1a. Even if you think in terms of regional organisations in 4 sla, you have to keep in touch wh the otrer regions. And whatever regions you have in mind, the importance of India cannot be ignored.8

7. In Seliz S. Harrison (ed), India and the United States (New York: Uacmillari Co., 1961), 0.53 .

8. From speech in the Indian Constituent Assembly on iarch 8 , 1949, erinted in Jawanarlal Nehra, Inda's Forelen Pollcy: Selected Speeches, September 1946-Apr11, 1961 (Deih1: PubIications Division, 1961) p. E. . 
Let us have a look at what a British author has to

say:

The preservation of both peace and the open society In Asia depends arenty upon Indian stability and growth. Between peking and sukara the largest, most efficient, and most quickly deployable military force is the Indian army, which has inherfted the tradition of battle trainitie, experience, disclpline, and organization golrg back over the handred years and more of its continuous esteblisiment. It already defends the Himalayan wall against Chinese infiltration. To the fast its existence reinforces Burmand the smali saccessor states of Inco-China. "io the vest, it contributes at one remove to the security of the Hidie East. Take asa the lynch pris, transiorm the Indin subcontinent Into a dozen defenceless, squaboling states-mard the whole of the Indian ocean and fiflea's exst codsts become an ared winere subversion and military intrusion 111 be impossibis to prevent. . . 9

Or, at what an American says:

- Indis compels consideration by virtue of size alone. And yet Incia also sticks out a mile from the rest of Asja, Arrtca, and the Hiddle East in the more critical sense that the Nehru goverment commands the broad nationwide support and confidence of the Indian people. 10

In fine, Inda's position in that part of the world is so outstanding that this Iong excurston in 1963 could be easily dubbed as a redundant, labored, acudemic exercise Were it not due to the fact that the United States policymaxers tendea to aet in that area as if India did not exist. We Will have to return to this aspect of the Enerican policies in Southern Asia during 1353 and 1954 in a later chapter. American Response to Changina Asia

For nearly five years after the end of the Second world

9. Barbara Ward, India End the West (Now York: Norton \& Co., 1961), p.xes.

10. Selig S. Harrison, o․ cit., p. 
War Americâd policies in the Pacific were still largely China-oriented, apart from her demiliterising and democratising mission in Japan.

In China, however, Herica's frienc and war-time? ally, Chlang xai-chex, having been recently mace safe from Japan and elevated to take hi. seat with the world s other four most poverful men in the U. in. Security Council, was faced with ancther, Gute difierent type of foe; viz., nis om people. The Communist iajo ise-tung rode to victory on the wave of populsr discontent. The generalissino was forced to retire to the Talkar island before the year 1949 was out. For the United states it as 2 mafor setback. The Aaministration arew the lesson that unpopular resiaes could not be sustained by military crutches made in dmerica. It was a recognition of the force of isian people's lapatience with the corrupt, inefficient and externaly bolstered tctalitartan reglmes, anc the U.S. government for an ephemeral moment of time semed to have been. thiriking of new policies in Ine with this lesson.

However, to China's "friends" in the U.S.A., Chiang's debacle appesed to be due to Anerican "domestic villainy", nothing short of a consuiracy on the pert of atate Dejartment offictals. The poverful China Lobby's clanor for blood was temporarily dianed only by the louder bangs of the North Korean attack on South Korea in June, 1950, culminating in Commist China's onn direct intervention and the subsequent 
military stalenate.

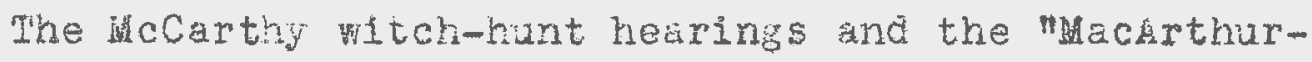
Fas-let-down" inquest led the partially paralyed finerian government to drat certain leszons from the Korean fir which superseded the chine lessons and found theti expression in a number of mutual defense treaties with the countries along the "Pacific defense perimeter". Mutual Sechity Programs were also inftiated.

As a result of its victory in the 19Es Prestaential election, the Republican proty $k a s$ inasarated ln the white House. The Republican right wing had already sald that the Truman-Acheson lessons from China were wronds. To then, the lessons from both China and Korea vere the sane: the Democratic "containment" of Comunism was "too passive and tiaid"; Communism needed to be "rolled back" ano people "Ilberated" wth the threat of "inassive and Instant" retaliatory might of America.Besiaes, this could be cone "cheaper". The new orientation of an alresay estabisted policy brought United States actions to bear on the entire area of Southern Asia in their fulness for the first time. The military alliance with Pakistan and the creation of the Southeast Asic Preaty Orgenisation Fere the two most outstandim expressions of this heightened concern for Southerm Asic during the first to years of the Revblicar Administretion.

In the next chapter will attenpt an understanding 
of the domestlc and worla dynamics of the evolving American response to Bouthern Asla's new awakning. Chapters III and IV 111 explore the actual flowering of this response. Phese chepters 111 also exame the impact of the new policies on Anerican relations with the countries of the region and on the1r relations among themselves. The coneluding chapter w111 state the findings and place thea aglngt a resume of the main elewents in the United states response during the period surveyed. 
II. THE OLD AND THE "NEW LOOK" GUD SOUTHERN GSTA

Having set the stage in the preceding pages we may attempt an ancilysis of the national and international requirements of the United States security goals and their emerging emphasis on military solutions to Soutrern hsia's problems.

The material avallable on this subject is already so roluminous that a comprehensive coverage here vould be 1mpossible. What can be done in this smil section is to merely attempt an interpretative sumary of the points necessary to the subsequent requirements. of the new strategy were the product of umerican policles in Southern Asia, nor has the impact been confined to that part of the world. Seconaly, much of this material is strictly not germane to the area of our concern. This explains why it was considered necessary to deal with it as a separate unit.

It was, hovever, felt that without taking the interplay of America's vorld comitments and domestic realities into account, the treatment of the subject would be analogous to tryind to understand the kiciss of a horse by taking a count and measuring theis frequency without paying attention to the source of its fury and native strength.

Although it will be preposterous to suggest thet Ameican policies in Southern Asie were at any time determined by exclusive regional considerations vithout reference to theili larger, world-wide context, it does remain largely 
true that, as this analygis wald show, Southern Asia was the forge as well as the battleground for the "New Look" armoun developed by the Eisenhower-Dulles partnership.

For a proper understanding of the chenges wrought by this "New Look" diplonacy ${ }^{1}$ we must look back and briefly trace the genefal picture of American militery posture in Southern Asia and elsewhere at the time when the "New Look" lense came into focus.

\section{7-51: Containment in Europe}

The power realities and general elrcumstances arising out of World war II largely dominated the Great Power relatlons through 1947. It is true that fateful changes had already been set in motion in the internationel arena, and in the Unfted States policles responding to them, but the Iruman Doetrine of Mareh, 1947 was the first defintte American response to the rapidy developing chill of the cola war which unoflefally announced the demise of the "ara of good feelings".

This Doctrine's operative formula offerlng unllateral help to "free peoples who sre resisting atteppted subjugation by armed minorities or by outside pressurentas intentionally kept vague so as not to lead to any interpretation of formal "entangling" understandings.

1. Horman J. Graebner calls it "in lieu of diplomacy", The New Isolationism: A Study in Politics and Foreign Policy since 1950 (New York: Ronald Co.,1956), title of Chapter 6. 2. Il.8. Department of State Bulletin, March 23, 1947. 
S1x wonths later, the Inter-Amerien Treaty of Reciprocal Assistance (or the Rio Treaty), which was essentially a formal, jolnt expression of continuing United States Good Neighbor Polfey towerds the Solth American Republies, was signed. It has not been "commonly regarded as a military alliarce of the United Stated. It merely perpotuated the earlier defense arrangements made during the War and collectivized the hitherto North American approach to the hemispheric problems, expressed initially in what has cone to be known as the Monroe Doctrine.

It was only with the signing of the North Atiantic Treaty In Apri1, 1949 that the UnIted States could be sald to have departed from its traditional policy of no formal, advance comituents for participation in European affairs ${ }^{4}$. Its phraselogy of "an attack on one as attack on all" boldy comitted the United States to definite actions and responsibilities.

\section{Xorean Var and Containment in Asia}

T111 the U.S.-Japanese Security Treaty, stgned simultaneously w1th the Peace Ireaty on September 8, 1951, the United States had no formal milltary comitments in Asia:

3. Janes E. King. "Collective Defense: the Military Commitment", in irnold wollers (ed.), Alliance Poliey in the Cold Var (Baltimore: John Hopkins Press, 1959), p.104.

4. President Iruman calls it "the first peacetime military allince entered into by the United states since the adoption of the Constitution". Harry S. Truman, Memolrs (II) Iears of Irialy and Hope (Garden City: Doubleday \& Co.,1955), p.241. 
Secretary Acheson's talk of "the Pacific Defense Perimeter" in a Preas Conference on January li, 1950 and the financing of Chiang's resistence to Civil har in China dia not amount to acceptance of formal obligations. The Chinese intervention in the Korean ar in lovember, 1950 finally "convinced" the U.S. Administration that the prospects of hao's turning into a secona Tito were wishul thinking 5 and trat a new Commist front had opened which would have to be "contained" The security arrangement with Japan, the erstwhile arch-foe of the United States was, therefore, the first step in that direction.

The Phllipplnes, horever, failed to look at the lssue in the sime lieht. They manted, in turn, to be secured against a remiliturized Land of the Fising Sun before it was itself secured from the Red tide. A defense pact had, therefore, to be concluded ith her on August 30 , nine days before the

5. In a speech on January. 1k, 1950 before the NationaI Press Club, washington, D.C., Dean Acheson pointed out that the Kremlin vias "detaching the northern provinces of China and - . attaching tirem to the Soviet Union. This process is complete in outer hongolia. It is neerly complete in ManChuria, and I am sure that in Inner iongolia and Sinkiang, there are happy reports from soviet agents to ilioscow. ... This fact that the soviet union is taxiug the northern provinces of Chins is the single most significant, the most inportant fact, in the relation of any foreisn power in Asia". The secretary emphasized that under no circumstances the United States must "seize the unenviuble position which the fussians have carved out for themselves. We must not deflect from the Russians to ourselves the righteous inger, and the wrath, and the hatred of the chinese people rithich must develop", "The Far Last and Southeast isia: The Basic postion of the United States", printed in American Foreigr Policy, 1950-55. Besic Documents, Depsrtment of State PubIication 6446 (Washington: G.P.0., 1957), pp. s.316-es17. 
signing of the Japanese Treaty. On September 1, the United States also signed the ANCUS Pact with fustralia and New Zealanc, arain as a guarantee of Japanese yood behavior. That completes the picture of United states comitments under the Denocratic Adriatstion.

Rasicaliy, the Trumin policy had been designed to meet Communt postures as they developed. It tried to respond to these challenges resolutely, but never by overspreadrat the dmerican involvemont. It extended help to lockl governments in Greece and Turizey to fight the Communist armed minorities. The Soviet blockade of Vestern access routes to Berlin was met by a heroic and costly airlift. The Soviet advance in dastern Europe called for the massive European Recovery Program throligh Wintch billions of dollars In ald were made available. The vorth Atlantic Treaty Organlsatior came into being due largely to American infiative and support.

In Asia, the American response was stmilarly marked by caltious resolution. It never threw diplonacy to the winds. To the Commist victory in China it reacted warily, seaping open the possibility that China right not cast her lot entirely vith the Soviet Union. The United States bore most of the brunt in opposing aggression in zorea. It then tried to strengthen the Paciflc aefense position by making clear commitments, realistically and recognising the futlity of spreading the net too thin. The result was that Amorica was not alone in most of the sltuations where action became 
necessary. The faministration tried to work th allies and through the Uisecingtions. When Machthur openly acvocated extension of the korean conflict, president rraman responded to the horld opinion and to the realities of the new power situation in hsia by relieving the five-star general of his command.

In short, the Triman-Acheson policy was Eered to the concept of limited pover. It as besed on the realiantion that, given the radities of worle polities, Communism could at best be "contalnea" but not "aestroys" in the near future. It, therefore, tried to reconcile to the aecessity of having to live with the menace tili the Red aplie was ripe or rotter enough to fall off by itself. In Asia, the fdmiristration showed appreclation of the forces of political and social ciante and did not attempt to iam them in mid-stream. For exaple, this vas 1 ts lesson from Chians Ka1-shek's rout:

- - what conclude, I bolleve, is that there is a new day which has daned in Asia. It is a day in wich the Asian people are on their ow, and knowit, and intend to continue on their own. It is a day in wich the old relations between east and west are cone, relationships which at their worst were exploitation, anc ahich at their best bere paterralisa. That relationship is over, ana the relationship of east and west wist row be in the Far East one of matual respect ind mutul helpfulness. We are their friencs. Others are their friencs. We and those others are wiling to help, but we can help only where we are antea and only where the conditions of help are really sensible and possible. So what we can see is that this new day in Asia, this new day which is daming, my go on to a glorlous noon or it ay arizale out. But that decision lies

6. "Long-tera, patient, but firm ana vigilant containment"

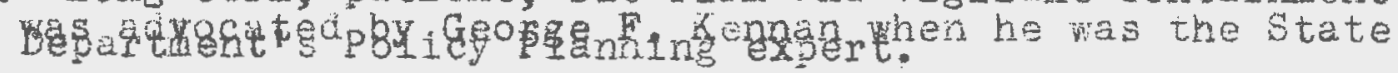


winth the countries of Asia and within the power of the Aslan people. It is not a decision which Eriend or even an enemy from outside can decide for them.

Again, presenting the fised 1952 Hutual Secur1ty Program, Dean Acheson stated that "poverty, disease, 11l1teracy and resentments against former colonial explostations are our enemles" in what he termed as the "vital crescent" from Mfghanlstan to Japan. "These represent turbulent forces", he emphasided and aded: ". We must assure that the forces of nationalism and of the drive for economic improvent are associated with the rest of the free world instead of with communism. ... [0ur prograin] is designed to... encourage the Erowth and survival of non-Commist political institutions dedlcated to the honest fulfilment of their basic needs and aspirations". 8

Thus, gensing the momentous changes that were occurring in Asla, the Truman-Acheson policy correctly decided to abstain from interfering or bamboozling these countries into Ine with 1ts own leltpolitik.

\section{8-54: A "Hew Look" Emerges}

Up to the end of 1949 the Democratic forelgn policles worked well and, y th few exceptions, enfoyed overwhelming public supgort. In farope, the Truman Doctrine, Harsha11 Plan, Nato, and the Berlin airlift had all succeeded in consolidating the Westarn position. There were signs, in fact,

8. Mutual Security Act of 1951, Senate Hearings, (Washington: Q.P. O., 1951), D. 5.

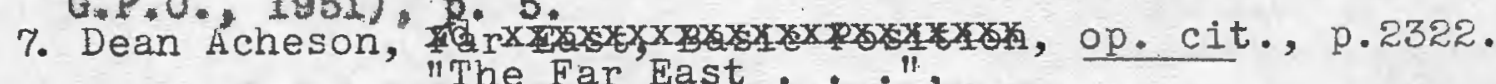


that the rapid recovery of strengti by hest Europe kas arousing the envy of its eastern neighoors. In hinerica, the acute commodity shortages resulting irom the war had eased; the mployaent situation was 1mproving; and, prices, aiter a spirallng loflation, were stabilizing. The nation vas fast developing a general optimistic mood and people tendac to forget the emotional and economic privations suffered because of the recent mer.

This happy state of affairs, hovever, proved to ise only the lul1 before a storm. WIth Chiang Ki-shek's retreat to Talan in December, 1349 before pummeli1ng Communist soldiers, the stuation in Asia fast acglired ominous hues. In the introductory chapter we noted the specially paternalistic feelings towas chiniz that had of yore existea in America. The substitution of 30 for Chiang turning China from a pra to a foe hac, therefore, the frony of a Greek tragedy. The memories of the sactiffees suffered not lor ago in subduing a rapacious hipoon for the sake of Chinn: started coming alive again. This was the beginuing os a great upsurge of frustration anc disillusionnent thet started snowalling into a partisan-lec search for scapggoats ior

9. Americin motives regarding Asia have been complex: Americans seened far iess afraid of entanglements in the orient. Here we coula spread the cospel, extend trade, urge reform, and difuse American ideas without danger of immediate political involvement". Selie a aler, The Isoletionist Impulse: Its Twentieth Century Reaction (New York: Colliers Books-paperback edition-, 1961 ) DP. K4- 5 . 
this "American loss". The uncovering of some Commulsts through the MeCarthy crusade leading to Congressional

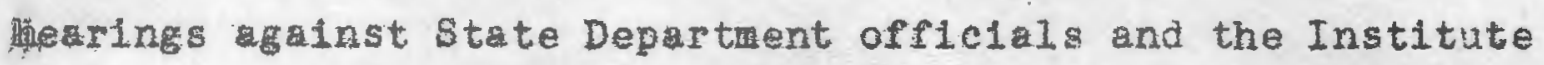
of Pacific Relations set the gublic mood into a fuse which was powerfully detonated by the Korean War. 4mericans had to bear the major burden of that 倠ar and suffered tremendous losges in men and materials. But, when Truman restrainod 蕰acartmi's march into Hanchuria and later relieved the General of his comand, he played stralght into the hands of the G.0.P. First of a11, people could not understand rhy 1t became necessary to ifght another war so soon after the last wr and for a country whose name wax most of them had even not/heard before. They could appeciate even less the bogging the

down of/American soldiers indefinttely at the imagingry 38 th para110l in a milltary stalenate. It went so much/the grain of American military traditon of fighting occasional herolcally and then spoedily returning home to normal vocations.

The success of the hero's welcome to racarthur and the later Congresslonal Hearings of his case did enough to arouse pabic emotions aganst the Democratic Administration for its alleged fallures in Asia. The right ing within the Republican Party, which conoluded that this popular enthusiasw gave them a mandate ror thelr Asia-first orientation, acquired ascendancy. The masa hyster1a and fmatrations whiped up by the wild charges of "offlcial defeatism and deafness 
toward Asla which extended from the presidency downI0 changed the nation's foreign policy mood rather rapidy, making it possible for the Republicans to turn that policy Into a comestic struggle for power. The Presidential election year of 1952 offered too timely an opportunity to be missed. The Republicans invelghed that every wound to America's intermational position since world war II was, in effect, self-1nflicted. The Russian advance 1nto East European countries was not the result of a power-vacuum, but of Roosevelt-Truman "tragic blunders" at Teheran, Yalta, and Potsdam and "others to follow". "On our Pacific flank", the Republican platform charged, the Truman-ficheson "villa1ny" had "substituted a murderous enemy for an ally and friend". The Administration had first "invited" the Korean War, "invoked the patriotic and sacrificial support of the American people", and, then, it ald not have "the will to victory". 11 The platform castigated the Truman "Europe First" orientation and attributed America's Far Bastern "fallures" to the Administration's "Asia last" policy when the Soviet Union had turned to an "Asia first" policy. In short, American pollcy had become "short on 1deas, short on understanding of

10. This is an accurate sumation of the Republican charges done by a Republican supporter magazine, flve years later: Life, "Truman, China and History" (editorial), XL,Jan,Ez, $1956, p .40$.

11. "Republican Platform of 1952", reproduced in Current History XXII, October, 195\%, pp.246-54. 
the natire sha metrods of the eneny, short on pightins wil to win the cold war"ll.

Wr. Dules becans the chief foreigr policy expert and wokesman of the kepublicin Party as well as later ntine best Secretary of Staten president Fizenhoned hed "ever hronn. He is saic to have "best articulated the thining of all tha architects of the national defense poliejesle of his period. In his article titled "A policy of Bolaness" in the Life issue of ay $19,135 \mathrm{~g}^{14}$ wr. Dulles characterized the policy of contiment as "negitive, futile, and immoral". ve are not morxing, sacrificine, and sending in order to be abie to live nithout this peril--but to be able to live int 1t, presumbly forever". The Trumer-tineson policies vere "treadmil policies, nich, at best mist perhaps [sic] keep us in the sume piace until ge drop exhasted". They pere "not designed to win a mar conclusively". He accused that "we now sponsor the Iron Curtin to cut off our atrecting poker; and thus we help to jive desootisn a lease on life" "There is one solutior and only one", he pontificed, "that is for the free vorid to develop the will to orguize the rans to retaliate irstantly aginst oper aggresson by fea smies, so that if it occurred ary here, ve conld and oula strike

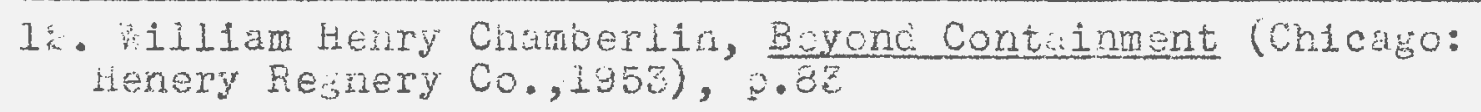
13. James Kiry, op. cit., po.lku-ki. 14. XXXVI, po.146 if. 
back where it hurts, by means of our own choosing".

Concerning the "captive peoples" under the "Godless Communism", Mr. Dulles wrote that the United States "should make it publicly known that it mants and expects [italics added] liberation to occur". The mere statement of that wish and expectation, he went on, "would change, in an electrifying way, the mood of the captive peoples. It would probably put heavy new burdens on the jallers and create new opportunities for liberation".

"Never had the illusion of American omnipotence demanded so much of hmerican diplomacy". 15 "The Republican program of action", Professor John W. Spanfer comments, Waparently envisaged the future secretary of state, John Joshual Dulles, marching around the walls of the Kremlin explre, sounding the call of freedom upon his trumpet. The walls would then come tumbling down, the enslaved people would be liberated, and soviet power would be forced to retreat.16

Hilles, not only promised to "strike back" and "liberate", but to do so at "eut-rate" price. In the Life article, quoted abore, Mr. Duiles had sald that the new policy's cornerstone would be "a balineed budget, a reduced national debt, an economical administration, and a cut in taxes".

He amplifled his 1deas later in an address to tho Council on Forelgn Relations on January 12, 1954:

15. Graebner, op. eit, $p .93$

16. Amerlcan Porelgn Paliey since Worla War II (New York: Frederick A, Praeger, 1960), p.101. 
we neeu allies ard collactive socurity. Or purpose is to mane these relations effertive, less costly. This can be cone by placin more relince on deterrent poter and less a obouce on locil defensive porer.

This is accepted practice so fsr as locil commitios

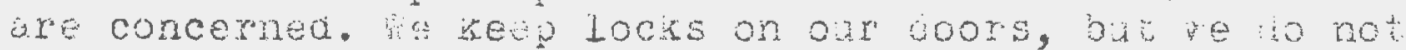
have ar wrod sura ir every home. We reply orinojpiliy

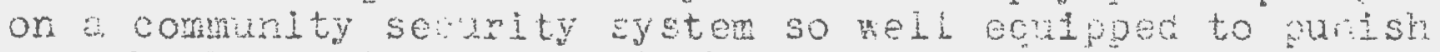
any who brear in anc sted that, in iact, wolia-be agressors are generally ceterrea. That is the nodern au of Eetting maximum secirity at a beartble cost.

What the fisenhower adnimistruci.n seess is a similar internationd security system. le want, for ourselves anc the other free nitions, a naximim deterrent at e beerable cost.i7(italics aduac).

Then he rote an articie in thx Horeien affairs whose general theme bas alto economic. Whe do not reea self-inposed yolicies that siu our strength", he rote and alded: "by now, rowever, the rew course is charted erd is guidia onr rilitary planing. As a result, it 15 non bosible to $s t$, ard share, more basic secunity at less co:t". 18

Thene is another side of tha "New Look" thirime mich

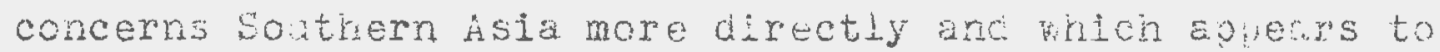
heve been at the back of Mr. Lulles' miac all the time. we have already referrec to the Fepulicar crusade,

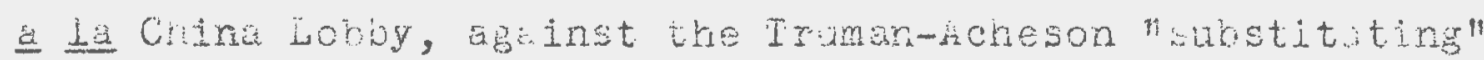
of hao Tse-tane for Chiane cai-shex. In the iffe article,

17. "Evolution of Foreign policy", Leoartment of state Builetis, Jamiary $55,1354,0 p .1 \mathrm{j7}-10$.

13. Jorr Foster Lulies, "policy for pece an Secuity",

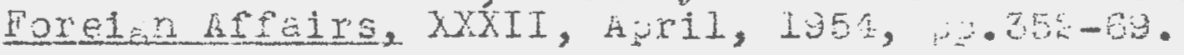

1. "ripolicy of Boloness", 100. cit. 
Mr. Dulles had prescribed that in Asia "a more of a hopeful, spirtted, dynamism could right the balance". In the Council on Forelgn Relations address, he listed "some transformations" which, on application of the "New Look" test, the Eisenhower administration had felt were needed. The first of these transformations he mentioned was: "It is not sound military strategy permanently to commit United States lana forces to ksia to a degree that leaves us no strategic reserves".

That his new strategy was hatched in the Astan eggbasket found confirmation in Mr. Dulles' Foreign Affalrs article. Having sald in a preceding paragraph that west European countries. . can create defense of the Continent", he warned: "Most areas within the reach of an sggressor offer less value to him than the loss he would suffer from wellconceived retallatory measures". Put this aghinst his following clarification of the "determce of massive retaliatory power" in the same article:

The essential thing is that a potential aggressor should know in advance that he can and 111 be made to guffer for his aggression for more than be posstbly can gain by it. This calls far system in which local defensive strength 1s reinforced by more mobile deterrent power. The method of doing so vill vary according to the character of the various areas.

In fact these three 1deas of, (1) more punishment for less gain, (2) western Europe's ability for Continental derense, and, (3), the "areas whin the reach of an aggressor" occur In that order in three congecutive paragraphs in the article. Besides, as James King points out, the theory of 
nuclear detexrence received "1ts first systematic statement" and became a "doctrine" of mastve retaliation "in reiation to the Indo-China crises of 1953-54". 20 (Ve will have opportunity to refer to this in the next chapter.)

That there has always been a strong expansionist feeling towards Asia, especially China, among certain sections in the United States was discussed earlier. After the debacle of that "tragic hero of history's Asian talellel the "Asia Firsters" frustration found new geal in the "New Look" of the new Adninistration.

Macerthur is reported to have told Representative Josaph W. Hart1n, Jr.: "If we lose the war to Communt sa in Asta, the fall of Europe is Inevitable; winit and Europe most probably would avold war and yet preserve freedom".2E In thus adrocating primacy to Asia in the United States foreign polley, General Douglas MacArthur certainly had company, both among the dead and the then Ilving: Theodore Roosevelt, Alfred Thayer Mahan, the Cabot Lodges, Herbert Hoover, Robert A. Taft, Joseph HeCarthy, Whilian Knowland, and the new comer, John Foster Dulles.

The reasoning of the nid-twentieth century "Asialationists" has been vell sumed up by Selig hdler:

20. op. c1t, 9.119

21. Phrase used by editors of Life, editorial, loc. e1t.

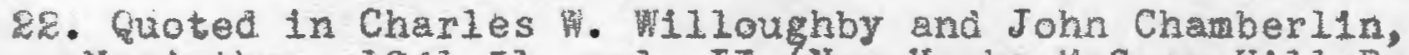

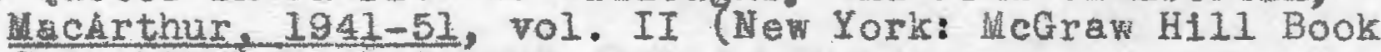
Co., 1954), Pp. 4EI-4R\%. 
This confident mood prevalled in 1951, because our prosperity was overtowing, our economy booming, and our. armed forces were bacired potentially by a stockpile of A-bombs. In Asia ve could flex our muscles without help or advice from poverty-stricken allies, for there our leadershlp could not be challenged (in the near future) by any non-Communist power willing to go our way. If, on the other hand, we continued to place the defense of Europe anead of victory in Asla, we would still be plagued with allies who would insist upon mutual consultetion and action in the campalgn agalnst Commism. Senator Kenneth S. Wherry best expressed this feeling of national superiority when he said in 1940: 'With God's help, we will ilft Shangha1 up and up, until it is just like Kansas City'.23

To restate the foundations of the strategy of the "New Look":

1. From the premise that the Truman-kcheson-Kernan "Containment" polley was too "negat1ve, futile, and immoral" and was almed at stagnating the United States into "living with the peril forover" the "New Look" reached the conclusion that Communism should be "destroyed" and not "contained" and the "captive peoples liberated" through a "uplicy of Boldness".

2. America's strength was boing "sapped" through defense expenditures when 1t was possible to achieve more security at less cost", 1.e., by "attaching a price tag to securtty". 24

3. The Republican victory had beer possible largely due to the mass hysteria and frustration caused by the "hala Firsters" and China Lobbyists over the "betrayal" of ChIan which had "directly led" to the "seemingly andess

23. The Isolationist Impulse, op. c1t, 0.407

24. Hanson W. Baldin in The Nev York I1mes, January 24, 1954. 
Korean War" wh its "tragic toll" of American life. Their paint of view was, therefore, accepted that sinee "old Europe" was capable of taking care of 1tself, Asia now must be made safe from the Red tide.

4. In terms of the international situation--supplementing the United States domestic politics-the most significant fact was that since Red China ("glutted with manpower") had no capacity to hit back the only way to reconcile all the above irreconcilables was to concentrate on "rolling back" the fed tide in Asia.

\section{Challenge and Response}

After prescribing "liberation" and "destruction" of the "Comunist peril" at a reduced rate as the therapy for resuscitating the sagging popular morale, the Republican administration had now to face the acld test of proving its efficacy and yet face the realities of mid-century international relations.

Chiang's "defection" and the "wasterully fought" War in Korea had been the, key issues of the lection campaign. Mr. Eisenhower had sald that he would "forgo the diversions of polltics. . to concentrate on the job of ending the Korean war. . . That job", he had asserted, "required a

\footnotetext{
25. Even though China was allied with Russia, the latter herself was behird the United States in the development of nuclear stockplies. She had, however, already exploded the fist atom bom in 1949 and the consideration that American superiority might not last forever must have also a "bold" policy formulation, while the United States alone basked in the atomic sunshine.
} 
personal trip.. . I shall go to Korea". 66 Accordingly, In the company of $\mathrm{M}$. Dulles he went to Korea shortly after his election. On the return voyage abroad the Helena, Mr. Dulles disclosed to James Shepley of Life' during the 1956 Presidential election year, they made this decision: If the Chinese Reds did not agree to "an honorable truce" within reasonable time the United States would renew the Ilghting and this time "fight to win". This would recuire alr attack into Manchuria which the Truman administration had "protected" by its decision not to cross the Yalu river "even by air". "Furthermore", to save lives, "Eisenhowever decidea on the tactical use of atomic arms". They dectdea to convey to the Chinese the gist of what these new decisions meant.

Hr. Elsenhowever used the State of the Union message to announce that he had rescinded the fruman order interloping the 7th Fleet between Chlang and $\mathrm{Mo}$. Mao woula no longer be saved. Mr. Dulles further confided to the Life correspondent that he himself, on his first goodwlll tour to several world capltals, told Hr. Nehru in Delni that the United States would "lift the self-imposed restrictions on its actions and hold back no meapon or effort to win". To make the point, the Shepley interview informs us that "Dulles had confidence in Nehru's ablilty to comunicate speedily with Peking".

26. Quoted in Graebner, op. c1t., p.101.

27. James Shepley, "How Dulles Averted 霍ar" ("Three Times at Brink of War: How Dulles Gambled and Won", title pase caption), Life, XL, January 16, 1956, pp. 70-80. 
Here, Life puts iffe into the drama. At E o'clock in the morning of June 18, $1953 \mathrm{Mr}$. Dulles was awakened by the constant uproar of the telephone in his bedroom. It was the watchdog officer at the State Department who had received an urgent radio message from Korea, across the dark Pacific. Syngman Rhee had "unleashed" the prisoners of War. "Dulles Iistened quietly, grunting an occasional 'yow' to acknowledge. Then he reached over to switch on the 11ght. And at that moment, as his f ully arousea mind shook off the fog of sleep, Dulles sa himself and the nation standing on the brink of a new war". Telephone from Dulles to Elsenhower. "Dulles found the President calm and ready. The Helena decision was reaffirmed. The Manchurian targets had already been carefully selected..."

But the Reds chickened out. "They continued to negotiate, thus accepting a propagands defeat. . They did so, Dulles belleves, because they had had unistakalo warning that further delays would no longer be met ith U.S. indecision".

"Thirty-nine days later the truce was signed".

Could there have been greater triumph for the "New Look"?

The interpratation that the threat did deter the Reds has been accepted by most of the American writers I have had a chance to read, even by authors28 who are

88. cf. Graebner, op. c1t., pp.15₹-54; Spanter, op.c1t, pp. I04-6; and Foscoe Drumond and Gaston Coblentz; Duel et the Brink (Garden City: Doubleday \& Co.,1980), po.111-14. 
othervise critical of the "New sook" orugeaciocto.

But nere are some fots which do not contoborate Mr. Dulles version in the wire interview:

1. Hir. Nerri is reported to have denied ar. Dubles suggestian that the liuian prime minister conveyed tre atomic attacis threat to ?exing

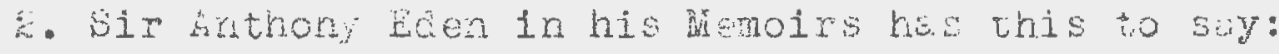
The release of priconers

mas \& ribht and a left for President lihee. A rioht at trie Comminists who were alumed and indignant ot so specticular iesertion; a lest at the haericans mo wore nomindily in charge of the canps and correspondingly embarrased in the nezotiations. 00

3. Dir. Dulles issiet the foilowing statem nt on June 1b, the same doy that he receiveo the morine cixil:

I have been in conference with the presiaent. . . Tris action [fhee's releasin the prisonere] wes in violation of the authority of the Uritec ivtions Convanc - We nave acted aro are actins in sooc fuith. presilent is combunicating ith presicent fhee in this sense.

4. in. Walter a. Robertson, issistert secretury of

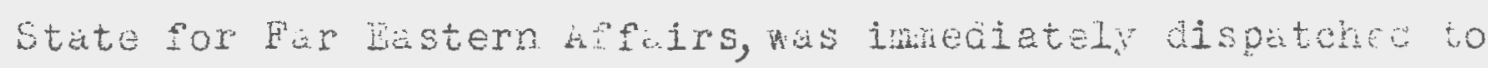
tulk to ninee in horeg and bring 'instint' pressure to bear on him. Hfter to weers of talxs hinee "guve in, promising; in writing that he woula neep his forces aräbr the U.N. Comiance" 3\%

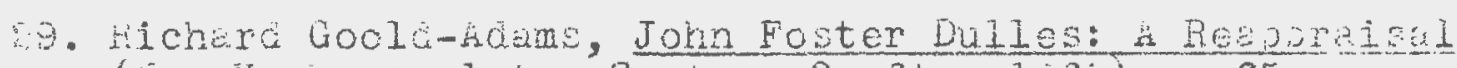
(Uew Iorx: Hpoleton-Century-Crofts, 130\%), 0.65.

30. Fil Circle (Boston: Gouzhton diflir Co., I96u), p...

21. Hobert J. Lonovan, Lisenhower, the Inside tory (Nov York: Haiper \& Brose, 1950) D.1.1.

3.:. The ilew yox Iimas, June ly, $195 \%$ 
5. Mr. Donovan reports that the "Rhee letters brought great relief to Eisenhower". 33 "The stubborn South Korean President had the Unfted States of America in a painfully delicate predicament and one that caused Elsenhower great worry". 34

6. The final settlement did not hunify" rorea, and did not secure "liberation" of the "captive peoples" from Commist bondage. The prisoners' repatriation question was solved by a compromise formula, the United States making equal concessions.

7. Lastly, one is entitled to wonder what was the purpose of Mr. Eisenhowever's election pronise to visit Korea, if not to tone down Syngman Rhee. Emmet John Hughes, who was Elsenhower's speech-writer, says in his recent account of Elsenhower's White House years that no decistons were taken abroad the Helena. 35

The conclusion would appear to be that in the first encounter between "rollbaci" and the world power realities "rollback" returned home to "containment", exposing the Dulles "hold" talk the he could not accept a Korean Settlement until the United States had given the Chinese "one hell of 11cking". 36

3\%. 1b1d, p.124

34. 10c. e1t.

35. The Otcel of Power: A Political Memolr of the Bisenhower Years (New York: Athenewm, 1963), quoted in "Witness in the Fouse", Saturday Review, March 16, 1963, p. 85.

36. 100. e1t. 
Characteristically, the "Mutul" Defense Treaty between the Unfted States and the Republic of Fora "desired - that no political aggressor could be under trie 111usion that either wil stand aione in the Pacific" (1talics added), 87 even as Comunist guns were giving the lie in Indo-China.

The second opportunity to apply the "Hew Look" strategy came simultaneousiy. In June, 1953 the East Germans rose in revolt against the Commulst regine. For some tine the culgling Ulbricht government had no control over the country, and Soviat tanks had to move in to restore "Commnist enslavement" of the German people.

What did Mr. Dulles do to seize this ready-made opportunity to "liberate the captive peoples"? The answer 19 Nothing, beyond openlng meal k1thens well atray frow the fest Berlin borders. Food packages had substituted for "liberation", again, so soon after the ougle was sounded!

Three years later the Hungrian people's uplising was put down by Soviet hassve intervention. Lulles pax reaction was typically Dallesian: "re do not look upon these nations [1.e., the Fussian sateliftes] as potential military el11es". 38

\section{Rearinted in Amerlean Boreinn Pol1cy 1950-55. Basic Documants, vol.I, ope.elt., p.897.}

38. The Ney York T1mes, October 28, 1956. 
Among all the manifestations of the "New Look" in Asia, two outstand as perfect examples of the split between the desire and the deed, between overweening reliance on "rollback" and unvillingness to take the consequences.

In both cases, the cost in money and men to the United States was sought to be made "bearable" by acquiring Asian "allieg" to do the flinting and in both cases herican diplomacy prid a heavy political price. Both resulted in the United Stgtes playing the colonial game of its European Allies. And in either case American policies ended up in alienating Asian sentiment rather than uniting it to thetr om cause.

One of these found expression in the military The allance wh the fledgling state of Pakistan, results ot this on Arerican relations with India, Afghanistan and the Arab countries were to prove disastrous. The second put the United States on the long road to involvement in Southeast Asla. This. Was the hatching of the strategy of "massive retallation" at the "brink" in Indo-China which was to whimpar into the "misbegotten paper t1ger" of Southeast Asia Treaty Organisation.

We will discuss the military partnership with Pakistan in this chapter and take up the United states imbroglio in Indo-China in the next. 


\section{Hehru Loses U.S. Faror}

India's "uncomitted" forelgn pollcy, which has been labelled as "neutrallsm" by the "committed", was earning bad feelings for her already. Her 'no' in the voting on the American resolution in the U.N. General Assembiy on February 1, 1951 branding China as aggressor in the Korean war resulted in a further stiffening of attitude toward her.

However, that the United States government in 1951 did not want to do anything which would be interpreted as offlcially writing India off was clear from the promptness With which it responded to India's request for food relief. The Indian request 1 tself showed that the Nehru adminlstration did not ant the feeling to grow that its attitude toward toward American conduct of the Korean war and the China vote meant that India was counting the United States out as a friend.

Nevertheless, it was not surprising that the strong opposition to the Indla Emergency Food Bill came in Congress from the same group of "Asialationists" which had earlier vehementy ralled that Truman and Acheson had "sold China down the river". How far this group was responsible for the clamor for an all-out war aglinst China came out more clearly In the MacArthur Hearings. Nehru's opposition to this enlargement of the War earned him many epithets which were to lead to sore feelings for a long time. The powerfull Knowland-wing Republicans had carried a "particularly vicious Anti-Hehru 
vendettil ana raisea tre cry for "getting toush with

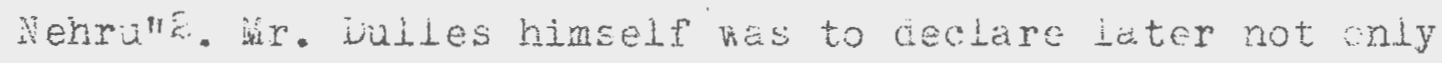
that the concept of "neitrulfsm" as obsolete but "except uncier very exceptionalcircumstunces it is sn immoril, and shortsichted conce tion?

The Nehru goverument had accordinly braced itself to fuce certuin ner trends in fmerican policies nhen the Hetublicans took of ice in Junarry, 1953. India's exclusion Irom nembership the political Corference on

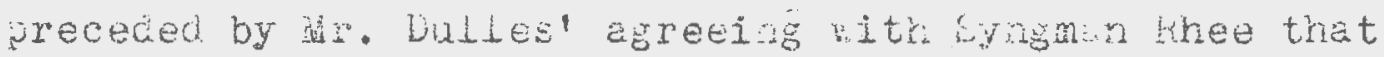

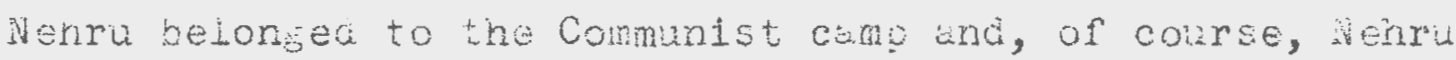
had said that bulles" "bold" specches "in regarä to the Fur List - . nuve c usec greve concern.. . From the point of viev of a pychosiz of feur . . they have had a had effect. - This talk wometimes of a blockec of Crinc or other sich step obviously is not the kind of un ly that leads to peace or settlement"

Concernig this deterioration in the two countriss relations Mr. Chester Bowles, Americur mbassdor in Wev Delini, wrote léter:

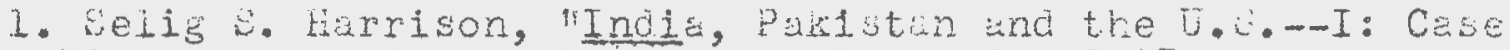
History of a listare", The Nev fevubie, CXII, fubust 10, 1053,17 .

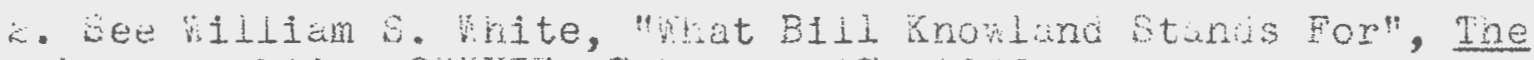
isbrepuotic, CXXXIV, Fenmury i7, 1956.

- Guoted in Graebrer, Wen Isolatinism, ò. cit., 3.846

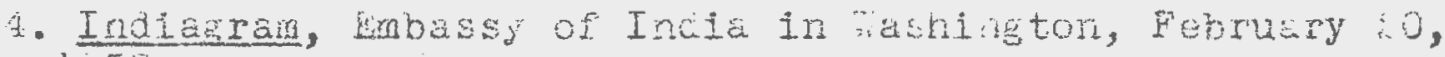
$195 \%$ 
When Secretary of State John Foster Dulles visited India in 1953 he was greeted with the utmost cordiality, and Indo-American relations still seemed on a solid footing. By the fall of 1953, however, the pendulum was swinging back again, influenced by our opposition to India's presence at the Korean Truce Conference and by videly circulated stories of Anerican intrigue in support of an independent Kashmir ${ }^{5}$.

About that time the Eisenhowever administrat1on decided to push through the arms-a1d deal wi thalstan. That issue had been under the Pentagon's deliberation for a long time and, prima facie, there might not have been any temporal connection between this decision and the recent trend in Indo-kmerican relations. But, as senator Fulbright warned in his speech of March 2,1954 in the Senate opposing the Pakistan ald decision, it was interpreted, not whout case, in New Delht as an Amertcan challenge to Nehru's recent forelgn policies and as an attempt "to force his hand".

\section{The Political Costs}

* In the introductory chapter we dwelt on the intrareglonal power pattern of Southern fista and Inda's special position in 1t. The region's common colonial baciground, expressing 1tself in a general mistrust of any loreign moves In that area, was noted and mention was made of the primary preoccupation of its peoples with the betterment of their economic and social conditions. It is against this regional setting that we must look upon the U.S. military ald to Pakistan.

5. Ambassador's Report (New York: Harper \& Bros., 1954), p. 231 
horeover, parstun's straind relaciors with its two reighbors, aforabistan and India were, abrt frot th: Har in fasnir ith India and the corfict over the pusntooristan issue ith fifonistan, due more to tre wutusities of their relutions thun to any basic aifferonce of outbos. One has just to remember Incia na Paristan's mutual binda and Wuslim ninorities, their comor boraers, comon river vater supplies, comon econonic inheritence, uro so on to realise the fact of their close interdepencence. Whese problems colid hive been solved ondy throush recosition of need for each other s wherstaning hich, after tre rocht trindic experierce ot commal riots, would hive come eventuslly. Some of these problems, such those regrralu the cund waters, exchunge of evicuee properties, etc., have in fict been larely solved.

Even in regaru to the Kashmir cispute, India jud Puristir fere tion movins nearer settlement. "Fev of the parties concerned, however", observes ar. Harrjon, "dispute the fact that in early 1950 the prosucts jor a Kashis settiment ere better than at any other time. The chace still existed wen uriman met secrety with the two siofs in Septenber $135 \%$ and February, $1952^{\prime \prime} .6$

is a mater of historical fact the Paistini Prime Ginister, wr. Hohanma Ali, had visited Delni in agust, 1953

6. Selib S. Harrisom, "Cost of wistse", Ihe NeF Pevubic, CXLI, August eA, $1959,0.84$. 
st wr. Wenra's invition and troy had but their siontures to a statement ixing lay, 1954 as the uedine for the spointment of a plebscite adulisistrator.

The U.S.-Pakietan arms pact camevitin montin of

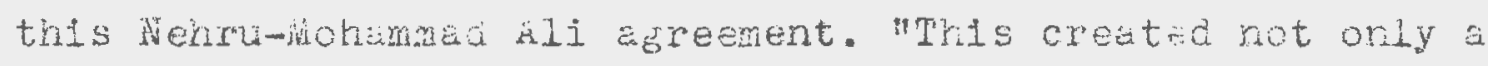
new miltury situation but a ren volftical situstion", as Mr. Wenru vas to expistn long afterwids in 1956 , "and the

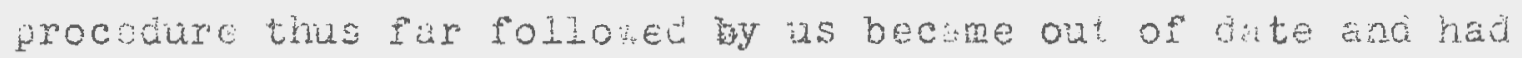
to be viewec afresh. Thet situation has become progresively arse becsuse of the flow of this rilitay aid to paristin . .7

The more active support of Irial by the soviet inion since about this tiae can be relatec directly to its effort to cash in on imerica's snue to nehru. Even then Achru stubornly refuzed to abandon his policy of non-alfermert. But for a goverrment hich professes to follow a nor-cont ital polioy tomas eitner power bloc, iefusil to respond to frierily overtures fron one side rould, iuso fucto, ppor to be uniriendy to that side, especially when the of fer is not preaicated on eny comitrent. It is sucmitted thet this way op lookine at Mehru's continued accepterce of helo from both sides le not less valid then the one thet sees Injia benefitile by playing one side as inst the other.

7. Seply to debate on Foreign Affairs in Lor sabra, wark ch,

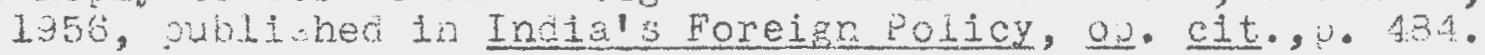


The effacts of this militsry tie-up intre pistar on

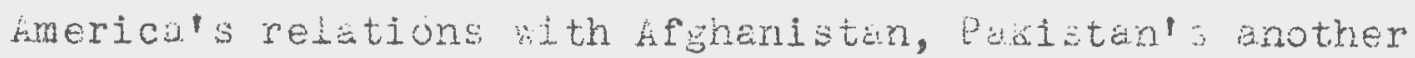
neighoor, were nore deleterious. The cocine of finerton prestige among the brab cointries and tho corresporiing iassing ging are also, to e great extent, we to the later enlargement of U.S.-Puistan alitunce into tie so-ceibod Baghas Pact of wich the United states nevei becume a member, a:a, on Irad's later defertion, had to be renmed an the Yeto or Cento Pact. India Deflected From Concern sith China

The timing or this nilitary aid to Paristur iac another sulf-aefeating efoet fror the point of view of the nmericun desire to deny to Commaist Cring ny ajus in that area. Incia has duays regorded China as the main danger to the countries of bouthern Asia, especialiy the rodtheatera nations: "Ana it is cortain that he [velird] did not unaerestinate the feare for hoir security that existed ir these

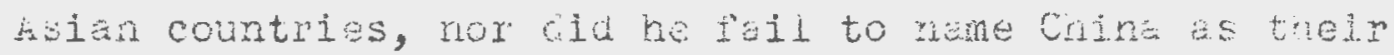
sourcen. 8

In fact, India had definitely become nore aprehentive of China sesigns after the forciole occupsion ot tibet in 1950. wifter that, efforts were mede to estubish some mechposts alorig the 2,000 mile border : ith China and border militia to petrol certan ares was created.

3. Posemary Brisserden, "India, Neutralsm and Sesto" in George donelski (ed.), beato: 6 btudies, (Melbourne: Eustri-

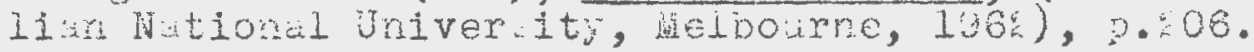


for high idtitude montia opertions me also scaured. Indian interest in the buffer st:tes of Hejel, sixrim, ind Stutar found heigitered expression. a specially valuerible

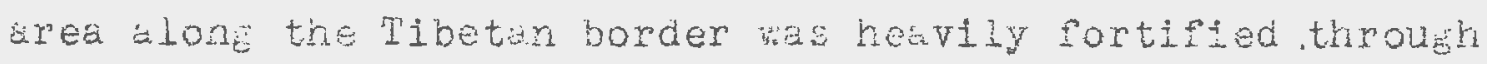
the Northeas Frontier igeney. Wenru's followin words are characteristic of that period:

hac how our interest in the interisel concition of hepal becomes sti. I nore tcute and persond, if I ruy say so, becusue of develojments across our borders, becuise or developents in Chind and rinet, to be frank. . . Therafore, mach a we apreciate the independence or wepal, we cannot risk our on security by anythin not cone in nepul mich peruts eitner that barrier to be crossey or othervise leads to the rexenine of our frortiers.

Out ot this heightened concern with Chind Nenra was reportei to have accepted a domesticaliy very unpopular step

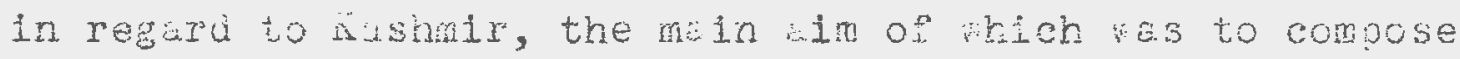
differences with Pekstan:

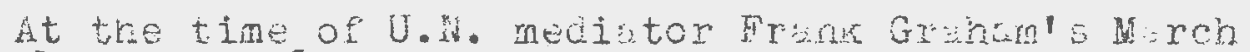
[195:]nissior [Iria and Paxistan] reached arreenent on a variation of the ofter-discussco partition approact to the xshoir cispute: Paristan rould et the moslem majorlty ast kamir territory on its sioe of tre existine cease-fire line, India woula retwin liridu tho Budnst-

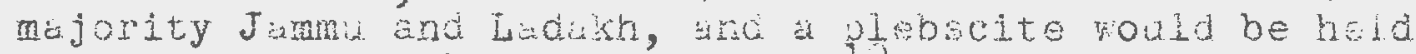
in the Hitulayan Vile of Kashir. 10

\section{Paxistan, As in A 11 y}

uilitarily, Paxistun's value to the United utstes ras

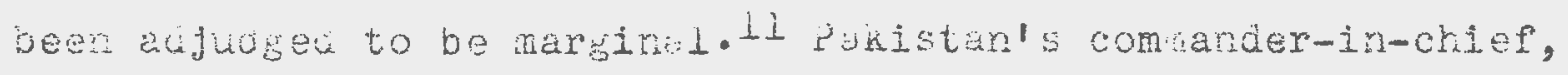

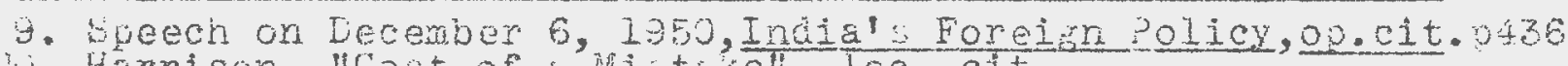
iv. Harrison, "Cost of a Mistane", loc.cit.

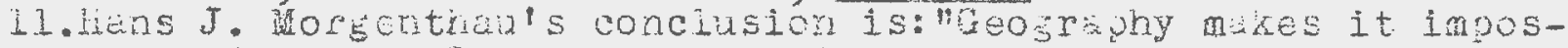
sible sor that pinistial army ia case of yr to give effective

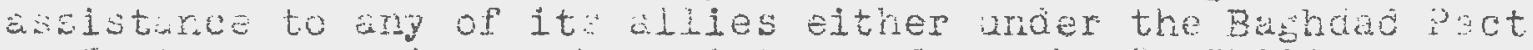
or Secto or receive sich assistince from then", "inilitiry

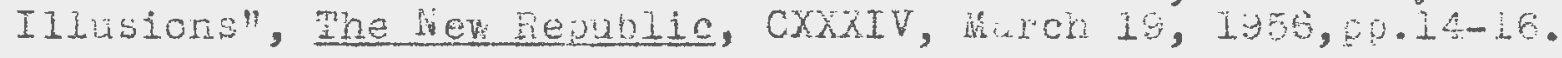


General bohama musa, himself is reported to rave told

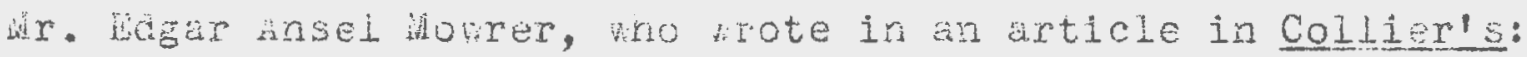

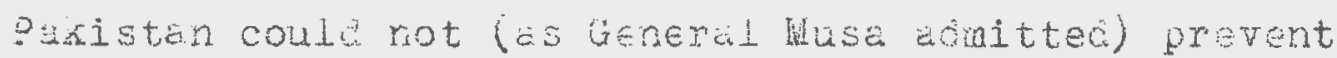
Commist lind forcei from dovaring south and occuying the great Irani or Iraci oil fielcs or the suer Cinel rone.

Does parist n share Aneric ' ${ }^{\prime}$ concern with the lommist threst? Here is an answer:

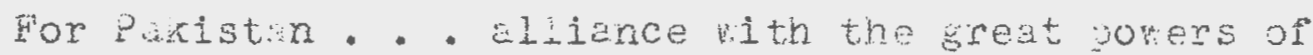
the rest--chiefly the United Ststes--nis ment, from the besinnine, security not fron Comminist Chini bit from

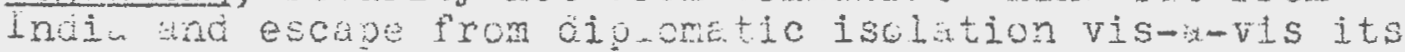
powerful neizhor. This much has been acmitted-at first anoficially, by paristani scholass ... an then by official spokesmen. . It (italics adiea)

From the above eviduition of the Unitea jtates ailitary alicnce ith Pakistan, it rould appor that tris vas a yholiy Wrones step.

Horever, 近. Jernegar, a State Department expert on Vear East, South hs and Arica wrote:". "I believe the advantages 111 sar outweigh the alsadvotages botr or the nations of that area anc for the Uniteo states and its associates of the free world". 14 ine must turn, therefore, to the stite Department's tringins on the vilue of Pukistun as an ally. in. Jerneguirites:

When Secretixy of itute Dulles took office. . he decided to have a ne. look d the ncle problem of ivear

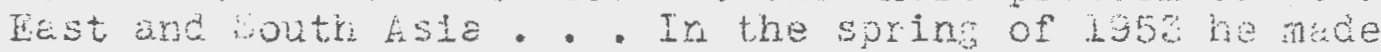
ar exterivive tour of the area. - . Wen he returned ha hed thic to say: "H udale dast Defense or anisation is

1.. Guotec in Harison, ibid, 0.50

13. Georze moalsi, in Seuto: 6 studies, ope cit., p.137

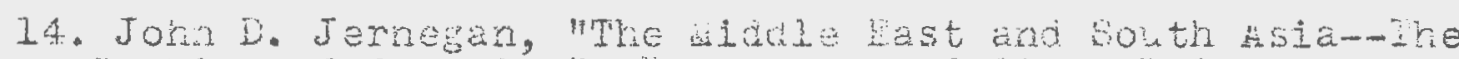
pronlem of Security", Degartment of ette Buldetin,

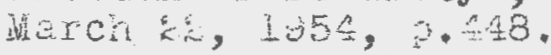


a future rather than linediate possibility. . However, there is more concern where the Soviet Unton is near. In general, the northern tier of states shows awareness of the danger. . While awaiting the formal creation of a security association, the Unfted stateg can userully help strengthen the interrelated defense of those countries which ant strength, not as against each other or the west, but to resist the common threat to all pree socleties". I5

As part of this "united states useful help", moves were initiated in the fall of 1953. By February 19, 1954 Turkey, America's Nato ally, was "helped" in signing a defense pact with Pakistan and on February 25 Presldent Eisenhoverer was "glad to comply" with Pakistan's request for militury assistance. Turixoy and Iraq wore "helped" to come together in 1955, then Barach and Ankara were fastened together by the Baghdad buekle and, a month later, the Baghdad Paet was born. The Long, Tangled Backeround

It vas hinted earlier that the Pentagon had for long been slezed of the issue of bringing Pakigtan into military alilance. This aspect of the story has been pleced together by Mr. Selig S. Harrison ${ }^{16}$. Marshalling documentary eviderce drawn malniy from British and American sources, he shows that this was originally a Britigh 1dea which was wold to the Americans. He traces the links back to an artlcle written in 1949 by a British geopolitician and vorld-renowned authority on Central As1a, Sir Olaf Kirkpatrick Caroe, twice Forelgn Affairs Secretary to the Foreign Office in India before Inda became free.

16. Ibid, 445

16. "Case History of a Mistake", o. cit, pp.10-17. 
In that atcle Sir ola's idea poser vacuum arising out of the British exit fron the Indian subcontinent by bringlag Independent India lnto some sort of arrangement to 111 the role which Imperial Britain had played in chacking "the bear that walus like a man" in its desgras on the HIdale East oll. However, by 1951 India's position in the cold war had becote clear. S1r olat, therefore, had to reajust his ideas and 1 in 1951 he wrote a

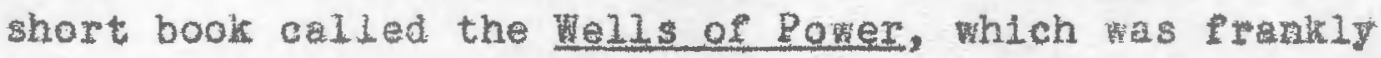
adaressed "to the Americans". In this he revised his geopolitical thinking and, construoting "a great oval or ellipse through elaborate maps accompanted by lengthy Haushofer-itke andysis" concluded: "A circle which falls to include Paxis$\tan$ [In a 'Northern Screen' along the soviet Centra] Astan border] is incomplete".

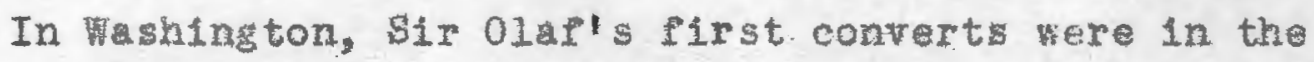
A1r Force, Mr. Harrison says, and he quotes the late Gen.Hoyt Vandenber: then A1F Force Chief of Staff, as giving this "frendy warning". to Anbasador Bowles (who was agalnt this 1aea) In September, 1951: whe are going to give you some trouble out there in Indis because we have our eye on bases in Pakistan".

Caroe proudy takes creat for influencing American thinking and earning Pakigtani gratitude:

My pakistan friends regard me as the inventor of the Baghdad Pact! I went on a tour of the Us for the British Fo in 1959 and had talis with State Department of ilcials and others on these lines, and perhap some of the 
exchanges we had were not thout effect. Indeed I have more than once ventured to latter myself that J.F. Dulles' phrase "The Northern Tler" and his association of the Us wis the Baghdad countries in Asia were influeneed by the thinking in the Wells of power. In that book I called those countries, "The Northern Screen"--the same 1dea really. 17

Mr. Harrison also mentions the names of the "heirarchs"18 and the interconnections between them: "Brituin's man", if not speciflcally "Sir 0laf's man"18 Pakistan's ex-President

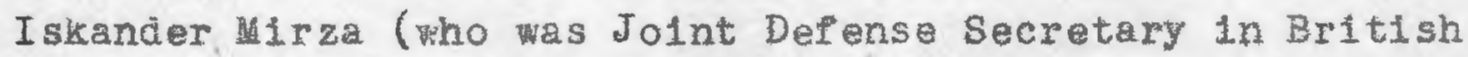
India and became Defense Secretary before ssuming the Presidency); "his good friend", Brig. Gen. Harry F. Meyers, the

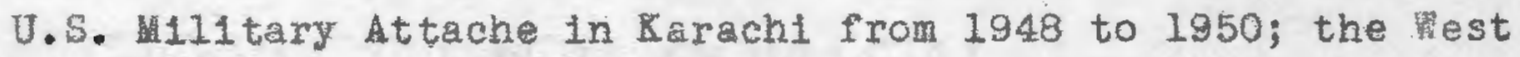
pointer, Gen. Henry Byroade whose appointment as Assistant Secretary of state for the Near East, South Asia and Africa marked "the turning polnt" (he also accompanded Dulles on his Spring, 1953 goodwil tour); Haj. Gen. George Olmsteed, Director of the Office of M1litary fisistance in the Pentrgon unt11 mid-1953; besides the Alr Force Chief of Btaff, Gen. Vandenberg, to whom we have already referred.

This researcher has checked most of the references clted by Mr. Harrison and, in addition, discovered more evidence corroborating his main points.

The London Economist in a July, 1949 issue wrote the followling under the byline "By a Correspendent":

17. 00 k, loc. e1t.

18. Observor's Philip Deane's term for senior Army officers and Clvil servants.

19. In 1958, S1r 01af wrote the Pathans, 550 B.C. - 1957 A. D. dedicating it to "ly Friend Iskander Mlrza, Presicent of Pakistan, First Hapng Those who, having graduated in pardan smong the Yusurzals, are admitted to a life of fellowsip in the honorable company of Pathans". 
Pakistar's strateglc importance has been greatly enhanced by a change of emphasis in the uiddle Eat. The traditional British view has seen the Middle East only as a bridge on the road to India, in that bridge the keystone of the arch was the Buez canal. Now the aeroplane has made the eastern lledterranean unusabie in war, and the importance st111 g1ven to the canal is only a decent tribute paid to Disraeli's menory. Today it is 011 that matters. The strategic crux of the ridale east is no longer Calro, but Abadan; Persla, not Egypt, is the prize; and so suddenly, bases in pakistan ought to have become more important than those of Egypt or Palestine.

That this article was obvionsly addressed to the Amerlcans is clear from: "Looking ahead ten years it is possible to see in the economy of pakistan one of the world's great dollar earners and dollar savers, strateglcally the leader of the Hiddle East" 20 .

That this British strategy vas in fact eventually bought by the United States can be illastrated from American sources. Mr. Dulles is reported to have told Mr. Arthur Dean, his "confidant" and "old law partner" this, regarding the creation of the Baghdad Pact:

He [Dulles] would say that the Jolnt Chiefs of staff were wried about the utter absence of any organized defense in the northern M1ddle East, the lack of anything by way of a coordinated military structure to prevent the Russians from taking the entire area. Foster would also argue that we mugt also sometimes do what the British wanted, and could not only be wways asking them to do what we wanted.21.

Mr. Jernegan, whom wave hlready quoted, mentions approving 1 the Turikish Prime Ministar as supporting the

20. Econom1st; "The Fole of Pakistan", CLVII, July 23, 1949, p. $0.175-77$.

1. Drumiond and Coblentz, Duel at the Brink, op. c1t., p.14a 
Pakistan-Turkish nexus "bearing in mind geopolitical consiaerations" ${ }^{2 k}$.

Calling Pakistan "a logical chandate for the milltary aid", which would give substance to an "1dea which has langulshed for quite some time", Williar H. Hessler, who served with the Fast Carrier Task Forces during 1945 and is author of Operation Surv17al (1949), wrote in the proceedings of the U.S. Haval Institute:

The defense line of the ant1-Soviet coalition of the West runs in a great irregular curve South and Bast from the North Cape of Norway to the Caucasus Mountalns. There at the easternmost margins of Turkey it stops cold. GreekTurk1sh-Yugoslav rapproachment is giving the line new solidity in its vital southeastern segment. But beyond Turkey, we find poterty, agrarian discontent, military weakness and neutral1sm-and therefore danger. In this great and neglected reglon of 1 iddle and South Asla, the leader of the western democracies find, a massive chalienge And in this area, as a consequence of basic geographic factors, Pakistan has a singular strategic importance.

He concluded: "The attractions of a United StatesPakistan entente are soundly based, because they rest on the solid foundations of m111tary geographynE.

Since most of the information relating to so recent a period is still highly classified, no definitive account can be written at this time. Yet, there is enough evidence to show that, although the Pentagon had become conserted to the British strategy long ago, the Idea could be sold to the State

22. 오. cit., p.445

23. "Pakistan and the Himalayas", LXXX, August, 1954. 
Department only in 1953, when the Elsenhover-Dulles new aplomacy mix became more amenable to military thining. That the ariting of Pakistan would not only be cheap but would fit in elsenhowever's election declaration to "Let the Asians fight the Asians" 1s borne out by a number of statements. Defense Secretary HeElroy, for example, compared the 3,515 required to pay, feediad house an Aaerican soldier with the $\$ 485$ cost of a Pakistan1 4 and that Pakistanis "were a warrior pande ... cough ... rairily six-footers ... rugged eaters of meat and weatnEs

Mr. C.M. Woodhouse, a British Conservative M.P. and an ex-Director of the Royal Institute of International Afrairs, compares the British oli interests and the American aim of "rolling back" Soviet Commism as the main national interests of the two countries in Middle East.26

That Pakistan wis selected for "rolling back" the Soviets 1 also clear from the state Department's own words:

The Pakistan Government had shown its awareness of the danger [of Communism], and in the state of the world today it did not seem good policy to rebuff those who think as we do and who can contribute to the security of the free old on which our own securlty depends.27

And yet we have seen how Paktstan looked upon the Communist threat even at the time the ald profrim was being mooted, not to mention her later hobnobbing with the Commust States.

24. Ne11 H. McElroy, "Military Assistance" in Foreign Aspects of U.S. National Security: Conference Proceedings (Washington: Comittee for Internation 1 Economic Growth, 1958) p.34.

25. Guoted in Harrison, 10c. cit.

26. British Paliex since World 2 ar II (New York: Preager, 1960) p184. ¿7. Jernegan, loc. clt. 
In his biography Nixon, Ralph Toledano says that on his return from a stopover in Karachi in December, 1953, Mr. Nixon, Ropubican Vice-President, had urged the alliance with Paxistan not for its purported defense value against Soviet aggression but for the very reason that pakistan sought the ald--'as a countex-force to the conflrmed neutrallty of Jawaharlal Nehru's India" " 28

We also know the shifting fortunes of the Baghad Pact and the fact that the United states did not intend, from the beginning, to become a full member of the Pact.

The military agreewent with Pakistan is thus perhaps the best example of the "New Look" preoceupation with Cominunism as a miltary threat, and of thinking of "roling" it back by buying up allies whose real concern lies elsewhere than with the "destruction of the Soviet demon".

28. Quoted in Barrison, 1oc. cit. Mr. Hanson Baldwin, The New York Times'military analyst in the newspaper's issue of December 5 , 1952 also gave this as the reason for extending military ald to Pakistan: "The problem which the Pakistan arms aid is intended to relleve... stems chiefly from the decline in power of the British Empire $\because$ But the postwar rise of nationalism in the 1 idale Est and As1a, Blus the increasing threat of Cominungm and Nehru's anti-westernism, altered the entire strategic pieture". 


\section{SEATO: THE INVERTED "ROLLBACK"}

The Hew Look" seedling, planted by the "Aslalationists", nursed and cared by Secretary Dulles with "bold" lullables, and nourlshed on a "budget-balancing" dlet, flowered into $t h$ e Southeast Asia Treaty Organisation in the backyard of Red China. But, it so happened that its strong, unsavory smells "rolled back" more firiends than enemles.

\section{Indo-China: The French "Country"}

Seato was a typically Dullesian solution to an old problem which had dogged the American policy-makers ever since VJ Day when the Japanese occupation ended in IndoChina, in the eastern wing of Southern Asia.

We have noted earlier that under the Japanese occupation the local leaders in French Indo-China had enjoyed some independence. Before they left, the Japanese had divided it into the three kingdoms of Vietnam, Laos and Cambodia. By the lddife of 1945, Vietnam's Emperor Bao Dat had already become a phantom figure and in lugust he abdicated his throne in favor of Ho Chi Hinh whose party, the Vletnam Independence League, better known as the Vietminh, had set up a government over the entire country. In September Ho declared independence of the Democratic Republic of Vietnam.

Following the Potsdam declsion, two separate parties of British and Chinese troops were sent to disarm the Japanese. The British, operating in the territory south of the l6th 
parlel, decider to interort their inisior for thensolves and helped the French in reesteblishing themselves ia trit area. The Chinese, or their part, let Ho continue in the north, hoping to exert their infuence in vietaw tnroub him.

Eo wer, fio Chi wirh ans the Fremeh decided to mane a deal in incon, 1446. I declaration was signed whereby the Frencr recompsed the hepubic of Vietna as a "free state, having its oun eoverment, parliament, army ano treasury, belonging to the Indo-Cinese feder tion wh the French Union". But, as Elien llamor woints in her study, The strugzle Por Indo-Crina, fio ChI in proved too concilistory to the French and the very substantial economie, wilitury, ard politic l concessions he ornted to them nere attacaed by otrer nutionalist grouvs. i

The Unitea states govermment at thit tine was unequivocally in favor of incepeadence of colonial termitories. Secretary Cordell Hull recalls foosevelt's conment

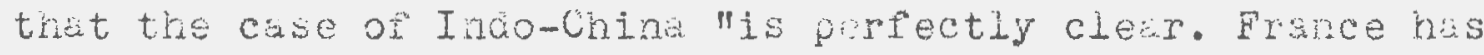
milked it for one hundred years. The peole of Inco-China are entitled to something better tian that". "The Vietninh had, therefore, plocec a large store by recent fineridus pronouncements expressir disaprovit of French ingerialism. iobert shajen reports that an imericun Intelligence officen,

1. (Starifora: Stanforj Uriversity Press, 1958), D. 124-55.

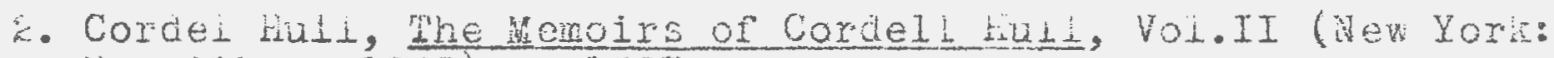
indenilian, 1948), 2.1597. 
who had parachuted into Vletminh's Jungle headquarters had found "unrestrictod affection for all Amerlcans". 3

The American attitude of those days contrasts sharoly

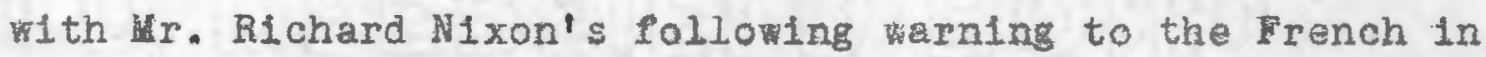
late 1953:

If your country (Indo-China) is to be independent and Iree, it is first necessary to defeat the representatives of Communist imperial1sm on rour sol1. Those who advocate (removal of the French troops from Indo-China) must know that if such a course is adopted it will mean not 1ndom pendence but complete domination by a foreign power. ${ }^{4}$ (italics added).

In the meantime, what had happened was briefly this. No sooner did the ink dry on the French-Vietminh agreement of Harch, 1946 than the French started preparing to restore their colonial rule over the whole of Vietnam. By August of that year French attacks on the Vietminh had started and by December, the plecemeal French efforts having falled, general hostilities began.

Up till 1949, the American government kept aloof from the golngs-on in Indo-China; but the success of Communism in China caused concern over the fate of Southeast Asta. In an effort to "contain" Comanism and to buttress the distressed French ally, the Truman administration recognised the French puppet Bao Da1's Vietnam as an independent state which was preceded by the Commist bloc recognition of the Vletminh. Dean Acheson declared that the "Soviet acknowledgement of

3. "The Enlgma of Ho Chi ilinh", The Reporter, III, January 27, 1955.

4. Quoted in Graebner, The New Isolationism, op. cit., p.159. 
this movement should remove any 1llusions as to the 'nationalist' nature of Ho Chi Minh's alms and reveals Ho in his true colors as the mortal enemy of native independence in Indo-China".5

Prance was extended material help but the Democratic Administration, conscious from the beginning of eventual French collapse, never threw. caution to the linds and never committed the United States to all-out participation or to a "war to win".

The 'Rim of HeI1' Thesis

Thus, when the Republican administration took over It saw the French garden in Indochina ablaze, fed by strong winds blown from the lungs of the Chinese dragon. When the fall of the French fortress of Dienbienphu became imminent in April, 1954, the shrewd French, aware of Mr. Dulles' messianic anti-Comanulst zeal, reised the wolf-cry with renewed enthusiasm. Hre Dulles, unwiling to spend on an expensive operation of fighting a jungle fire, offered instead two \&tom bombs and more "massive" hell-flre from nearby a1r-borne fighters. 6 However, when the British and Mr. Dulles' own Chief of Army Staff, General Ridgway, whispered that ground forces would be required immediately following the air-strike, the Fire Chief relented. Inereafter, Mr. Dulles decided on a Pee-saving

5. U.S. Depertment of State Bulletin, XXII, p.244

6. Janes shepley (Life, "How Dulles Averted War"), oD. cit, p.72, quotes $u r$. Dulles telling him that "at the same time two U.S. alrcraft carriers, the Boxer and the Philipplne Sea steand towards the South China Bea. Abroad were their tactical alr groups armed ith atomic weapons". 
"postur of strength" to zeep the French and British from "capitilating to the Communist negotiators at the Nine Nation Geneva Conference. Mr. Dulles used a two-pronged pressure on the negotiations: one of "united action"--his "go-it-alone" wish having been scuttled by the leaders of Congress whom he called for a special briefing--and the other of a peranent collective defense organ1sation for southeast Asta. The story of these pressures and the resentments they caused all around has been well told by $r$. Chalmers $\mathbb{H}$. Roberts ("The Day We Didn't Go to War") ${ }^{7}$ and Professor Charles 0. Lerche, Jr. ("The United States, Great Britain, and Seato: A Case Study in the Falt Accompli"). 8

However, Mr. Dulles had used the occaston to develop his earlier thesis of "nuclear deterrence" into a doctrine of "massive, instant, retaliation" of "more moblle deterrent power" to be employed "at places of our choosing", in his article in the Forelgn Affairs issue of April, 1954 from which we quoted extensively in Chapter II. Reflecting later wth an eye on the Presidential election in 1956, Mr. Dulles, In the Iife article-anso referred to in Chapter II--ppadefully sald:

You have to take chances for war, just take chances for peace. Sore say that we were brought to

7. The Revarter, II, September 14, 1954, pp.\$1-35.

8. Journal of Politics, august, 1956 , reprinted in his Readings in International Politics (New Lork: Oxfora University Press, 1958) pp.89-100. 
the verge of war. Of course we ere brought to the verge of war. The ability to get to the verge without getting into the war is the necessary art. If you cannot raster 1t, you inevitably get into war. If you try to run avay from it, if you are scared at the brink, you are lost. We've had to look 1t square in the face-on the question of enlarging the Korean $\mathrm{W}_{\mathrm{r}}$, on the question of getting into the Indo-China $V^{2}$ ar, on the question of Formosa. We walked to the brink and we looked it in the face. re took strong action.

It took a lot more courage for the President than for me. His was the ultimate decislon. I did not have to mare declsion myself, only to recommend it. The President never flinched for a minute on any of these situgtions. He came up taut. 9

While Mr. Dulles was perfecting "brinkanship" the Geneva Conference produced a solution agreeable to all Ineluding the French. The American delegation did not sign the Agreement but stated that the United states would "refrain frosi the threat or use of force to disturb" the decistons. 10

Nevertheless, the Geneva accords were found lacking In "gome situation that at least wo could cull a modus yivend1" which Mr. Elsenhowever had earlier sald the United states was porking forl1. From June $z$ to 11 , even before the signing of the Geneva Agreement on July 21 , a Conference on. Southeast Astan Defense was being held in weshington anong m111tary representatives of the United States, Brita1n, France, Austzalis, a11 from outside the Southern Asian region, to eind a better

9. Jariss Shepley, op. clt., p.78

10. Depertment of State Bulletin, July 21,1954

11. The Her York Imes, Apri1 EC, 1954. 
"modus Vivend1". Southeast Asia is of "transcendant importanee to us", Mr. Elsenhowever had sald on Murch 24 and on Apri1 7 he added:

You hate row of dominoes set up, and you knoek over lirst one, and what wil happen to the last one 1 s the certainity that it will go over very quickiy, 12 meaning that if Indo-China fell, the other Boutheast Asian "doninoes" rould also topple dom.

It was, therefore, essentlal "to save all of southeast Ala, if it can be sared; if not, to save essential parts of 1."18. To this end, hurried invitations to whoever vanted to come and join were 1ssued. "The countries which indicated their intention of being representedri4 met from september 6 to 8 and the Southeast Asla Collective Defense ireaty, popularly known as seato, emerged. After belng ratifled by the various nember states it came into effect on February 19, 1955.

Fe sha11 now turn to an examination of the main provisions of the Ireaty to see wether and how far they come up to the proclaimed alms and methods of the "New Look" strategy.

Who H1I be "Sared"

The provisions releting to the areas protected by the Ireaty are most loosely constructed and do not admit of a clear definition. Article VII reads:

As used in this Treaty, the 'treaty area' 18 the general area of South-east Asia, including also the ehtire territorles of the Asian Parties, and the general area of the

1E. Guoted In Bonovan, Elsenhoper the Inside Story, onc1t,p.861 13. The Hev Iork Tires, Hay 12, 1954.

14. Collective Derense in Southeast Asia, (London: Royal Institute of International Affairs, 1956), p.1. 
Gouth-rest Pucific not incladin the pacific siea north of 1 degress 50 minutes north latitwe. . .

The explesion "the Pacific area north of zi degrecs 30 mirutes north latitiden, (sed $\mathrm{ms})$, accorain to one interpetation, "excludes lon: Kons and Formcsa as also Koree znd Jsun from the benefits of the Treaty, but anemican, fustraijan, British, French ard New Zealand territories in South was isia and the South west pacific" soith of the line nould apear to be covered, desjite the stubenent made by iar. Dulles, in a rejort on the Treaty transmitted to the United ststes senate on 10 rovemner, 195, that the Linitation ot the suerican comaltment uncer articie IV (I) to Commuist aggresslor reilected the specisl position of the United atates as the oniy party hich does not heve any territory in the ireaty area". 15

Indonusia, Burma, ana Ceylon are clearly yitin the areas covered by the Treaty, athougr these trree stutes,

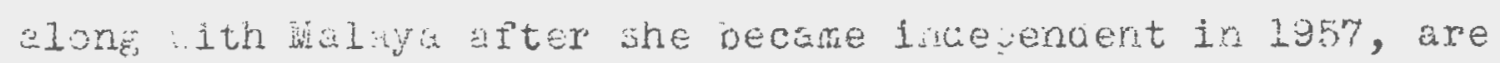
not members and have refiaec to do anyturg ith secto.

Similarly, the ststes of Cambodit, Laos, ard "ihe free

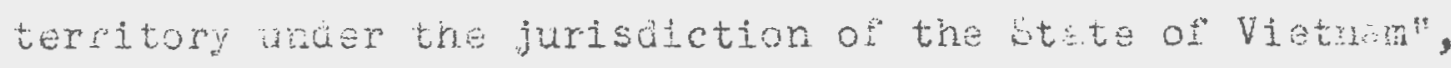

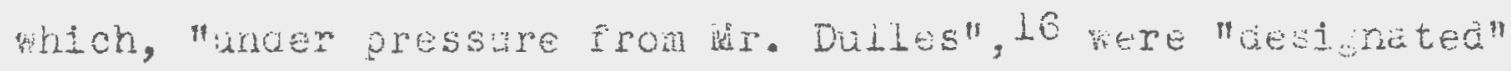

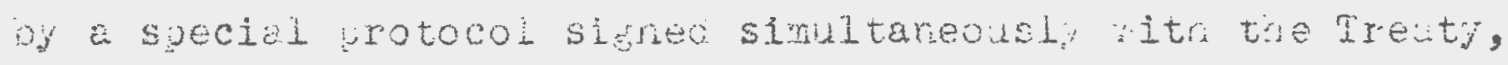
ruve nevor shown over-ebgrress to seek seato's good offices. The prime Hinister of cumodia has verenerty denounced beato,

15. Iijd, pp.1i-1:.

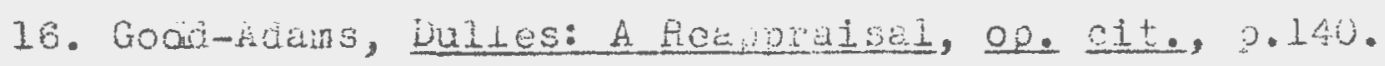


and scorned the idea of seeking its protection. 17 the new Coalltion Government of Laos, installed on June 2k, $196 \%$, announced on the same day that 1t. Would no longer recognise Beato's protection and that Laos would abide by the F1ve Principles of Peacepul Co-existence", according to a report In the New York Pimes of June $3,196 \mathrm{E}$. (The earlier Laos Government also had "eschewed any alrect technical or economic ald under Seato auspices"18.)

What are the aims and purposes of Seato?

\section{Security Aims}

A. Overt Military Aggression: By Article IV (I) of the Treaty each slgnatory would consider that "aggression by means of armed attack in the Treaty area against any of the Parties" or against a "deslgnated" state or territory "would endanger its own peace and safety". In such an event, each party "will act to meet the common danger in accordance with its constitutional processes".

The corresponding Article 5 of the North Atlantic Ireaty, by way of comparison, comits each party to regard. such an attack as an attack "against them a11" and to take nforthwith, individually and in concert with the other Parties, such action as 1t deems necessary, including the use of armed forces".

B. Situations 0ther Than Armed Attack: Paragraph (2) of Article IV provides that mif in the opinion of any of the International Organisation, XX, 1, Winter, 1958, p.17. 
Parties, the laviolability on the interoty of the terwitury or the soverejory or poitical inopenuenee of any Party in the treaty sres or of anj other state or territory to

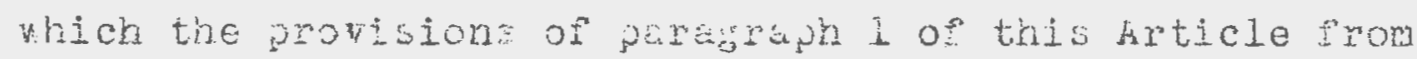
time to time apry is threatened by any inct or situation

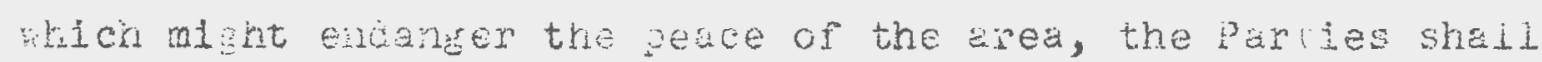
consijt imenitely 1 order to agree or the weasures wich ghould be taren sow the conion werence".

It must be noted thet any action non the territory" of ä "chsbnitean areals excluded by hrticle IV (3) "except at the livitation or wth the consent of the Governmert concerned". K. Ecoromic and Social Aims

The hortative Pacific Charter, prociaicing a Eureral statement of principles, wa dran, accordine to Mr. Mules, to rake it clecr that the sesto poners "iere seexing the velfare of the Hsin peoplos and nere not promotin 'colorialism". This anc the Preamble to the Mreaty, and its irticle III specifically, wrovide, among oth shimoleths, for copperition umone the sicnatories "ir tho finther developuent of economic medsures, ircluding tecrnic: I assistance desiched both to pomote economic prosens ind social wis $=1$-being".

We are now ready to subject these aim of the Treaty to ine test of weato's actual perforance over the years. It economic and icclal alms have aroused little eurtruversy 
sud we may derl wth these first.

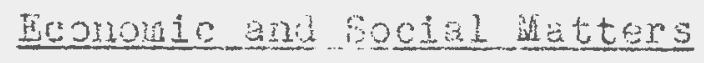

Altovgris the actual umountis gpent are not avidable 19 the leports of the seato annul hesting mention postess of

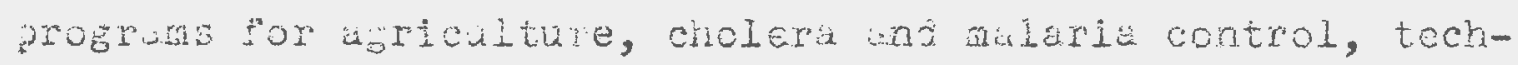
alcal trainirg, metereolobiai research, conninty development,

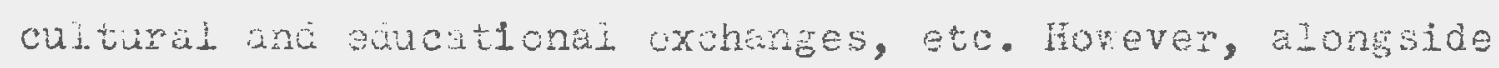
these activitios, the Reyorts cite equely, and sometimes rore, funchently the country-uide wic beins received by these areas through such U. - - supported projects as the Colomo plar, the Technical Cooperaton insion, the Wutus Security Program, Expont-Import Bank, the President's Fund for Astar Lconomio Development, the Arivuitural irade Development and Assistance Progrun, etc. These are other internaionel ajencies dolng economic and $30 \mathrm{cial}$ asistince vork in the area. With tha existerce of these well-knt schemes serious cuestions srlse dout the jesiruility of makin a primrily militury defense orynisution the moinm for chameling conomic assistuce for which it car never be adeguately and competentiy eutuped. For a detailed ciscussion on tris point refarence wy be nsde to Professor Bratbanti's excelient article. Wiltary Efilescy of Seato

rhe pleasing eiphony of the sourds Seato and Nato notwithstaning, the two orsaisations are kordes apext in B. Budet estimate: of 836,060 for $1952-60$ vere reportad "covering tre costs of civil and military heatounters and the previous proerus whertiken by the Oroansition". 20. Falph Brubanti, "The Southeast isia Collective Defenee Treaty", Pacific 4ffeis, $\mathrm{XXX}$, Decenber, $1357,02.207-8$. 


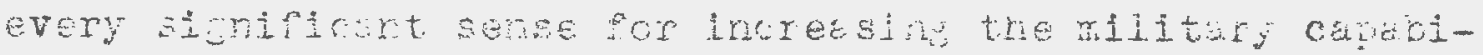
lity of a cefanse orbuistion agsinst exterral attacx.

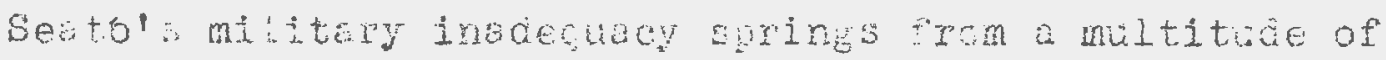
civses.

Althouth seato $1 \mathrm{~s}$ a regionel or anistion for wouthest

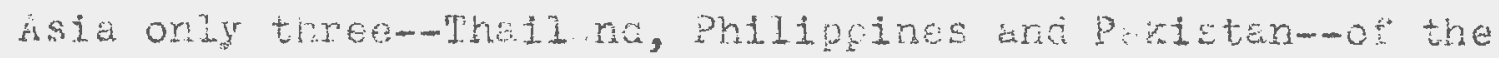

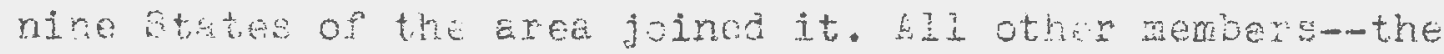
Unites states, Sritsir, Frunce, Nev Lealand ard Austraia-are outsicers.

The only alm of wr. Dalles in organisig secto to combat Commulsm notuithetwaing, the cther sijnatres to the Ireaty, notably Pukistancl, refused to feel similerly concerrec. The United Stutes, therefore, had to sign a sepurate "understandine" wion roula limit its purticiption in seato only aguinst Comunism ith reguro to the "augrecsion by weans of armed attack" proviso contined in paragraph I of Article IV of the Treaty.

The way paistatumenipulated entry into aesto trops interestin: sidelight on how sometimes the Jnited itstes has allowed other countrias' interests to dictate her foreign policy. Luring the Indo-Crinese peak crisis joriod, after br. Dilles hat been asked by Congressional leaders to

fi. "AS fur as Pakistan is concernea", Hr. Hamidul Huc Chouchiry, Pexistan' Foreing ifinister vas to explisin to the paisistan Nationi assembly in lyb6, "the most notabie achlevencht of seato is the reartirmition by the members of our stand on wastritir and Duruncine ith Aggranistan". Foreign Pelatione (Karachi: Governont of Paxistan, 1956$), 0.56$. None of these ialls uitrin the aims of seato. 
sound out other states regarding is projected intervention in the war, he made feverish efforts to get sore bisan countries iso to give his jlans a sembluce of "urited cetion" Parietar has not invited. but soom Paistar raised a Rea scarecrov. Professor George vodelsin guotes a Karachi dispaten of Jily 1., 195 empasising "Commiet suoversiun" problens puxistan as pacine, particulariy in its esstern Fing anc proclaimed that the lithreat of a Communst attack oo th1s seven-jear-old comtry . . Is not remotefre. Professor hodelski then notes that over one thos sand aleged "Communts cnd feliok-travellers" were arrested. Puristan's

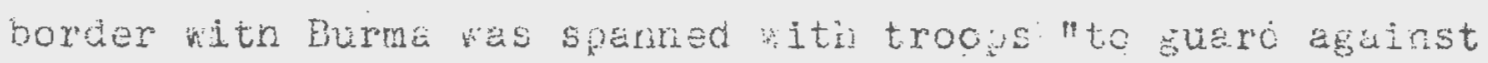
a possibie Communst drive throush Burma ard Theilindi. Palstan sent her Zafrullah shan in June to Wablaston to show "Hts intertion" to join seato. In paing, on the other hand, the Patstani ambasador entertalnet Crou En-Li and others over toasts to peristan's deterwination to further develop "the happy and hamioious relations now subsisting between the two countries". 23 professor hodelski remaris:

Pakicten joined as an associate of the beato stites, but no one believed to t fear of Chima layed a sinificunt purt in that decision. The comminist dunger, sugdenly played ap in 1954, has not been noticed since.

In the process, the Uniteo states reletions ith India, Efgranistan, and Burna, in particuler, and with the

.6. $00.01+, 2.131$

3. Ixxixy, Loc. cit.

:.4. Ixidare 10c. cit. 
other states of the region reacied a lon ebb.

Sone observers have even felt thit the emergence

of what is cilied the "Asian-African" bLoc, as a separate eritity can be triced directly to the creation of Seato:

In the lipht oi all that has heppened sice 1354 , one of the most interestin aspects of soato is that in practice it marea the beginoing of a new phase in the osttern or behsvior of the uncommitted. After that sunmer the idea of bijoinity besin to lose its grip. Insteac of the feeling of incrasing compulsior to join one sice or the other in tha cola var, a nore flexible international order began to appear.

It as only aiter ceato's birth, ajoin, that the Afgran Eovernment started gettin Soviet tachnicinn a a miltary heip and the Crinese Comminte started revaping the Cambocian army.

That the ssin partrers are in 10 position to ado to Seato's strength neterielly is anittec by themselves. In any case, they are frenir sooit it:

Tre other day the prifie winder of puistan, describing the Baghaid Pact, used ratrar striting language. Fe seid: zero plus zero plus zero plus zero eruls zero. His point was that unless some joweril country like the Unitea fingdom or the United States Fis in the Bsghad Pact fith its bigmilitiry apparas, idl the other memers of it, from the point of view of arnatuent, were relstively zero. There is arother aspect of it. Wher a cointry considering itself zero attiches itself to some figure, it is the fisure that counts, rot the zero, obviously.<6

It neeus haraly to bo added thot in the beotian arisis sent

of 1961, when other members of seato/token forces in sipjort

of the United states decision to Lrid arines irinalano, ouly

5. Cooid-fidams, op. cit, 2.141 .

66. Jahihal nehru, Incia' Foreian policy, selected soeches, 1355-57 (Delhi: Public tions Division, 1958), p.364. 
Pakistun excused herself. By tuis time, Pexistun had sirstclass army, thanks to haericen arms, but then she ras becone an fmerican aily not because of her anti-Communism.

dso much vas never expected of fustraliz, sritaln, France or New Lealand by way or actual contributions to sato's military strengtil. Thelr satisfuction ith seato an their reusons for joining it would sopear to be based on the consideration that the United states, for the pirst time in ner history, accepted military comitrents in the area and, thereby, undervrots their own irtereste there. Hustralia snd New zealand were already covered by the Anzas Pact, but the "Austrilian Govemment has repeatedy insisted that if it should bocome necessary to fisht to protect fustralia, it is much better ti do the sightine in ref ghooring courtries then in our ofnll?.

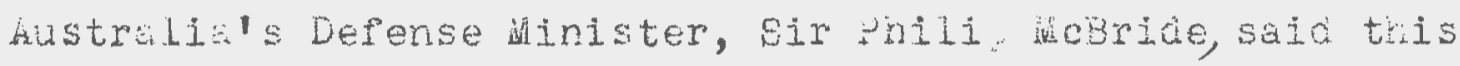
in so nary words. Wth reference to Australia's Soato membership, he stoted that it was imortant "to maintain the asp between fustraliz ard the present nichwter mari of tha souihmara flow of Commism" anc that hustralia must "nold the Comminists at the furthest point acvantabeous to us, and we rust consoliate our strengtr there as cuictiy as possiblent8 (emphasis suppiied). Sir philip of course camot biame his northerm ne1 ahbors if they sinow no reat enthasian for his resolution.

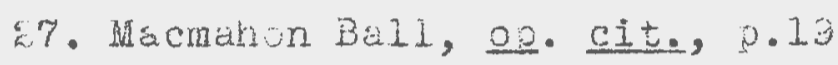

se. quoted in locelski, oo. cit., p.78 


\section{UOA: The Kingoin of seato}

It is obvious that any military effectiveness which Seato any possess at any time depends on the attituae of the United states. How does Anerica look at ner comitments to sesto? On June $: 5$, 1958 the secretury of stute told a greas conference:

I think you mow what certainly all the treaty aenbers knov--that it was ägreed sno that it was understood frow the very beginning that ve would not attumb to est bilish a force-in-oeingto ineto comperabln to the force-in-boing which is assigned to Nato. We nove to depero primerily upon an appropriate cooperation of local forces-in-being With the mobile striking pover of the United States which is avaluble in the vestern pacific and vinich is aviluble to be used wherever it neess to be used". fos

That nikes it clear that so far as the United states is concemed, 㨁. Dulles nould rely solely on her "messive", alrborne rucleur reteliation and expect the "locai forces-inbeing" to supoly the Asian marpower to "fight the Asians". That ar. Duiles intended U... purticiption in seato defense only in case of a thira korld ar becoms farther obvions, reuging his above statement along "ith the foliown:

Thit does not mear turnine every loc: 1 ver into a a world was. It does not meen that if there is a Comminst attack somewnere in Asia, atom or hyorogen bombs 111 necessarily be droppea on the sreat incustries of Crina or Rissia.si

Hovever, back in lo54 little aid Mr. Dulles realise that the ristng boviat might woul soon make his "rollo:ica"

E. U.S. Departnent of Btate 3ulietin, Jure $5,1956$. 30. "Policy for peace anc Security", Foreinn affairs, loc.cit. 
strategy obsolete and rould leuve hin incaphle of fistins any other ars except local, conventonil ars ar wich ne was not prepared. Let us see how beato has worked in actual practice.

Uta In Acttion

It is elaimed to seato's creit thet ro overt Comunist

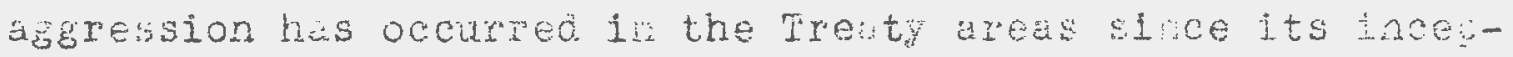
tion. Since none or the member states his territorias contiguous to the Commuist states, the question of ageresion aginst trem can arise only vicariously. Whe situston in the "Cesignutea" areas of Vietrum, wos aric Canbodia ras contnued as it existed at the tire seato came or the scene.

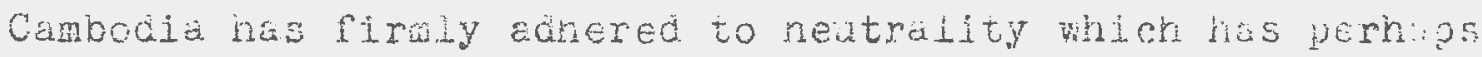
survivec becalise of her stubrorn refusal to let secto "protect" her. Fighting in Vietnin has spread much turther South. The

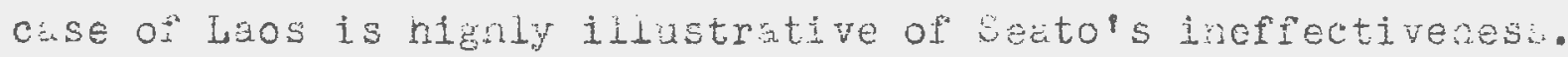

The newrast thing to s hostile commist move was the North Vietawase comploity in the Rathet Leo rebelisor to ards the closing of 1950 . In thowe militur srimishes the United states encourager action throub the juited it ations and the "seato conferees alscussen the posibility of finding ways and means to maintain a United itstons 'vresence' in

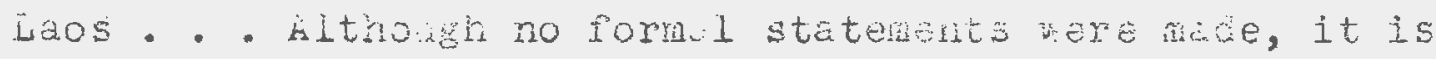
knon that seato rembers subseuently used their infuence

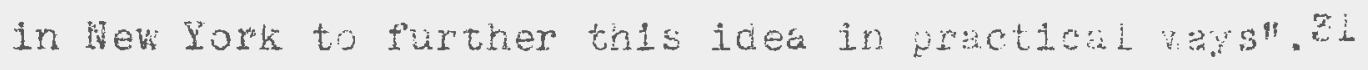
Current History, XXXXIII, February, L960, 2.08. 
Eroiessor Paciforu further remirirs:

The mild action by seato is notahle for the Laotian situation appeared of theid to involve the rind of threat to peace arid secirity rich the boutheast sisia Coliective

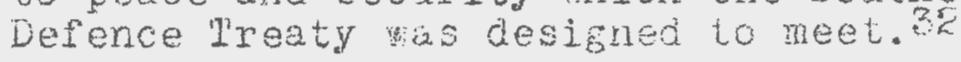

Seatols this brection in the ses of sh obvious

Commist agression maxes it clear thet the rund strategem of "masive retaliation" nas a mere tal and wa impotert to deal with situations in nich "nuclear sne ar-borne pover" iare not possibie to deploy.

Subversion: Seato's nishtore

hovever, to contirie to consich seate's role ith reference to amed Commist attack ony is to ibrowe the actual realites of the situdion in outhesst hia. Even before sesto wes creates a charge in Commist techriches fron open confict to sub rosa methods nas aiscermbie as early as 1351. The Seato Council at its senong and neeting roted:

- - He ure reed ith the unelentiaj cameign

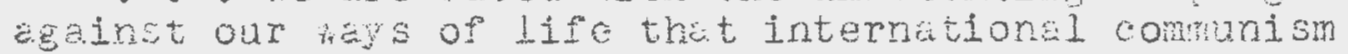
is wiging . . At different times, in yatioj places, he see Insurrection, terrorism, jolitical presare d.d

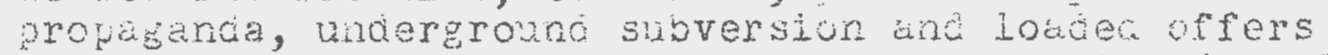
of economic cooperation, attem ts to pervert ans exicit the raturbl aspirations of free peoples towars aconomic and social bettemert. - . Subversion, which has aisys

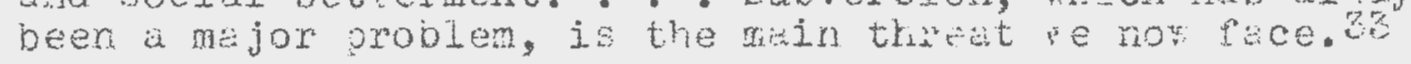

Is Seato erulpow to meet such a crallenge? The Trect provisions dealin" with "ary situctor or fact" have been stated earlier win reference to mich ore bit is

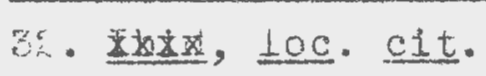

3. Seato: Eecond Annuid Fevort, 0.13 . 


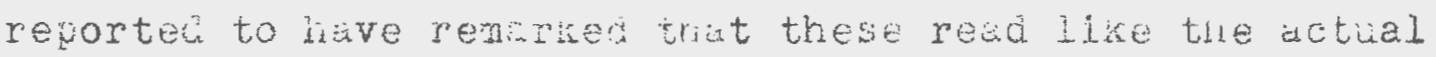

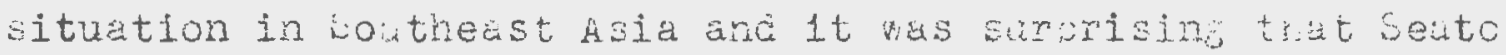
räa rot beer in continialis session.

The cuestion of subversion bristles with tiorny problexs. Walter Lippman even charged that besto is "the first forkal instrument in modern times which is desigred to license international intervention in irterna diffics".34 It must be clesriy unaerstood that the sejurate "uraerstancing" sisnea by ir. Lulles applies oniy to "overt Cormurist sgeresion". So fir as subversion is concerned, the unitea stutes obiiomtion to "consalt inmeoiately "ith otier prities in order to agree on the musues which should beteken for the con on defensel ander Paregraph of irticle IV, iz not thus limiteu. Irl the case of un open atack from the outsica it may

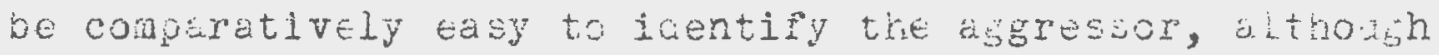
occisionally it iz not so esy. But, how and wh is to deaide wether or not an interial rebellion is Comurist-irspired and is not a seninaly nationalist expression ot populin discontent? Professor Ball has parodied the idea thus: "Is it to be assumed thint al subversive activities are loiructed Fron winout'?", he asks and then points out that "if the ord suversion has any meanin by bich the last tro regines in Trailund cane to porer.

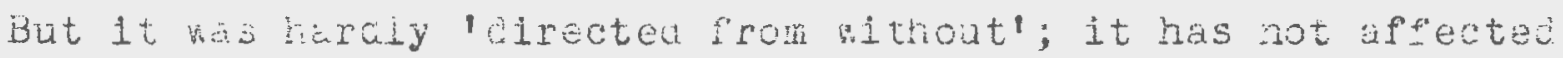
Thidinds territorial integrity and has given Thalland eone

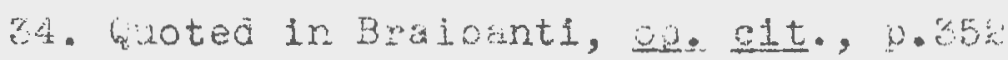




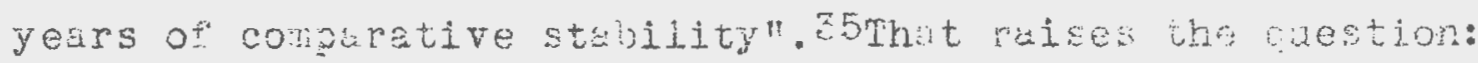
How for is it right to allor hmexican ans to be usea by

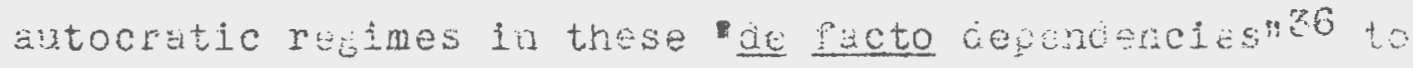
Malotuin their "conparative stabiluty" by suppreasire legitióte iocal Grievinces?

horeover, it is difficult to see how alon sunterrinen permed tor of conmulst infuence can be iammet ithout outlabing Conmuist parties it up by further seato action, whexer necessary, ulin the territorial precincts of "urotectall states. iuch action wold certeinly open ioodistes of internationi eriticism

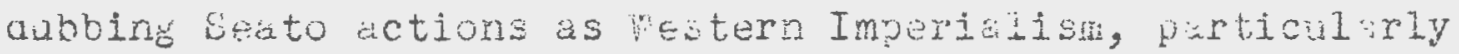
in a sensitive ared were past memoris are still so fresh. "The fact is tnat", as wuin F. Stanton, ex-U.S. kmbassador to Indilnd observes, "assistarde from other courtries is nut the anster to Eubversive activities witin a courtry; subversion can on be effectively counterea by the joverment anci the poople acting in unison". 77

That precisely is mot hat seato 1 s equipos to acnieve. Hr. Dulles' overraiance on massive nilisuryews, by its very obsession, freciuce noruing ati tre jeo le to build slow, denocritic resistence to Comanisu. Fe sar oriy tro teetrin in Comprism's open jav which rase it inpossible for him to reaiise that the leds en in by smiles as veli

25. Macmanon Ball, 오. cit., p.:3.

26. Janes ning,Jroues this aescription for soutr foroa, Fornosa and so.th Vietrim, op.cit., 2.l31.

27. Edvin F. otanton, "Comnanist pressures in Truilind", Current Eistory, XXXIII, Februry, 1960. 
as scare by their sconls.

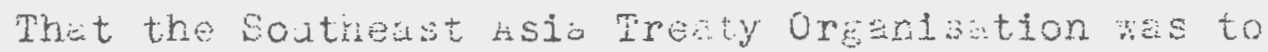
prove so totally inadeguete to its tass has been due as much to the realities of Southerr asia as to its afects at conception. In the nons of Professor HEns. J.boraentrau:

It [Seato] vas intended as a jesture of defince, as as an act wich woula convey initiative sro strergth witere actual inflative und strensth vere lacking. is sich, Seato was siated to tare its place in that series of pretertious, yet hollow, yronouncenents wich range from

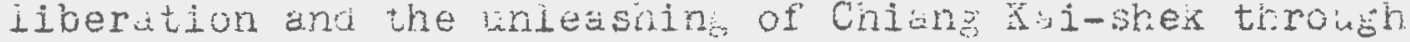
azonising reappraisal and the "new look" to tre brinis of werz.

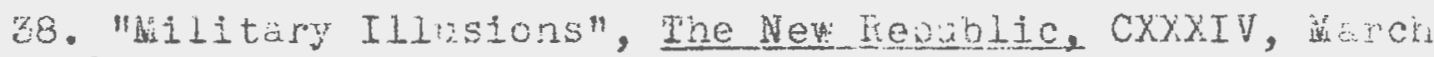
$19,1356$. 


\section{CONCLUSIORE}

Southern Asia saw itself receiving more attention durisg the first two years of the Elsenower diministrition than any other provious Anerican goverment hed ever cared to jestow on it. This new concern, hovever, spew out of policies and circunstances wich unappily led to uncertekings chat were misconceived as neli as ineffective. on bslance, the inited states policies apeared to huve beon resionsibie cor the mergence of a stron mistmist of Anerican ains in the area vithout any coutterviling acriievanents.

The sources or this misconception and the atterint inefrectiveness of policies were manifold; bat, in the final unalysis, they sprang from the basic postubates of the politicul pillosopny of certsin poreriul elenents in the Revublean echelons which, due to a fortutious combination of tood luck and partiskn manivulatton of popdise Susceptiofities, came to the fore to ards the end of the Trumen Administretion.

These groups have sometines heen, sol-afsut, called "isolationists" in international polities, when actualiy they merely wished to keep aloof from the aissipatiag internecine strugistes of the powerful ituropgan coutrifs. st other times, they nave selected the more attractive $r_{\text {inde }}$ of Americs-Firsters, when in fact they were looking westward to Astin merkets across the Pachfic. 
However, by the time the United States could arrive at the usian scene, Chins alone had escapec from finling under buropean dominarce. But China was a Iarge, sprabling country and promised to be potentially the bigest miret in the mord. The urge for trade has iven a spiritualist and welifarist dimersion wen religious groups of various cenominations sought to rin the millions for Christ. f velrd compound of raclial superiority, money, and morals made Chira's mystecl puld the loaaster in the posturd flight of the eixgle.

With this background of material and emotional irvolvement it as not surpring that ith the rull of a "riend and aliy", Cniang Kai-ghex, in 194j, this group's excessive sense of frustrution over Crind's loss to the Commists forno exaggerated expression in a vituperative and fuli-triroated cry aginst the Truman haministration. The stalemated Korear har suplied further fuel to widely held illusions of imerictn superiority anc invincibility. Hac Herbert Hoover asserted for nothing thit "the potential strengtin of this nation is the strongest ting in the whole noric. ... mmerica cannot be cefeateü"? I h e "Asia-Firsters" or "Asialationists", as they have been called, chargeo that it vas the Truman-fickeson policy of "softness" towards Communism hich had "stustituted" háo for Chiang, had "invited" the aggression in Gorea, and then fought it "watefuily" rith unnecessury cost in fmerican 


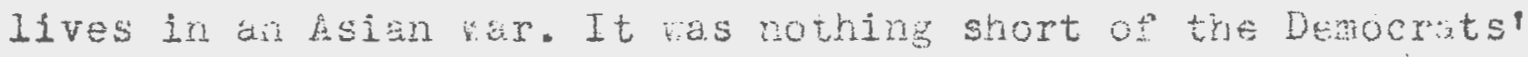

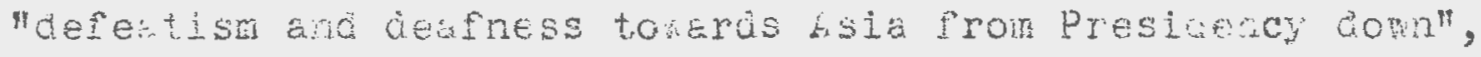
they anounced from pupits and nousetops, wich ias respon-

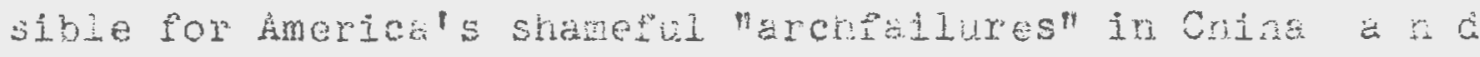
Korea.

isplying the same partisan lopic to tre other areas

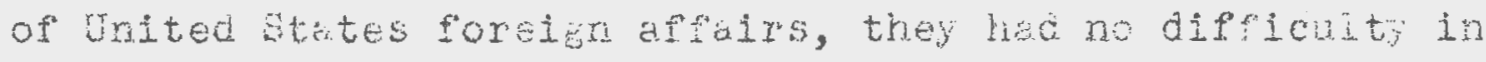
blaning the "too tiuld and immoral" concept of "contadnont" for the ensiavenent or Last Europeur people by the soviets. Trumb policies vere "treacilil polleies", they inveienec,

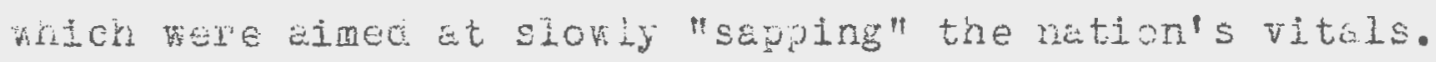
America, the ricrest and the nightest netion in the vorlo, ü. not have to suffer the torment of impotently "I1ving Porever with the Fed peril. wad so on. Throlizh a series of carefuliy plinned dre wiciy publicized prinests on the "Commanst-infestee" Stete Depertment the Republicans whiped up enough mas hysteria to meke their charges accepteole to the vuble zt large. They tailored thejr la5s presidential election platlore 1 so mainiy with an eye on this popular mood.

In John Foster Dulles they found a reve besich who

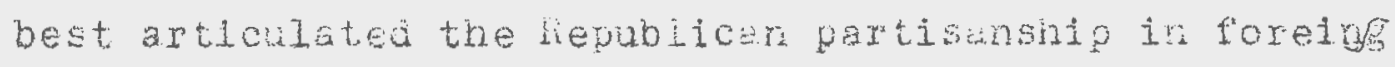
policy altrough he had been intiately associated in high

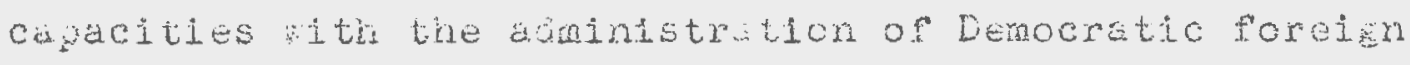
policies, dr. Dulles founc the prospect of a comandirg postion in a Fopulican aministration too tont Iisin to 
restrain rin in his criticism ot Trumar policies. He declarea that America's "massive retaliatory might" coula not only "deter" a vouia-be Commist agsressor, but coula "roll "iin backl as effectively. He nent a step further and, ith an Gur to the traitional concerri of business ith taxation, pronised to vanuish tho ied foe at a "much recuced cost", Lower tian the Denocrats' on unsuccessiul "contairnent". He resurected tre imase of hmerican onipotence in a ray mich any master of demagoy woula envy: Vith regara to the yoopie oenind the iror and bumboo curtins, he assertea, America mast maxe it elesr that "it wants and expects liberition to occur", aro these curtains would shatter in an "electripying Dey", liftrig tre Commaist yoke.

Whether the Repubilans would succees in "rolling nacz" the Communsts was as yet to be seen, but they aid succead in rolifis the Denocrats out of the white House. Having ridden to victory on the crest of the current popular weve, they had 10\% to reconcile the mutualiy incomptible aims of "more security at less cost" into a prospm of actich. They rove together their "concern" for Asie, promises of tax reouctior, Duliesia: "bolä" talk, and a brand "New Loox" on strategy for mid-centiry Anerica emerged.

The baste thinsing berind this strateged can be summined ds Pollows: In order to prevent americals vitality based on private eaterprise from slowly eroin thromin ine goverment speniis, economies must be affected. Win e "the 
Dis spending is, of coirse, the tho billion ve pay for security", the hepublican presicential cuncidate had explatned in a spech in Baltimore on september is, 135k, "here is ware the Largest savings can be made". But if the threat of Commuism had to be "destroyed", malntenance of adeguate militury power was aiso escential. The only way to reconcile these 6 bo oposing urges wes to do scne rotninkin, on ierense strategy.

As far as Lurope was concerrec, it as decilec that it ria received a disproportionate share of attention from the Democratic "tidrope-Firsters". Other "areas nearer to the Commant aggressors" would now be made citadels of the free World's defense. Commantst China had most recentiy incurred the wrath of the American people. Besides, she was veak. By concentrating popialar attention on her it wis possible to serve God and Manron at tle scone time. horeover, it as possible to find cheaper Asian alles, and sharth thr costs ith them, the wnole prosrum coula be made "bearsble".

This sharing of the costs was easy. The United States bready had an overhelming superiority in wuclear stockiles ara air ana naval striking cuecity. It could supply tois component to the alliance system witnoit much additional cost. In fact, this mould prevent incustrial leyof a and "Saping" of kefercar prosperity. The waste occurred mainiy in mintuining smerican marine and sround forces. It cost as much

five times/to $k \in \epsilon_{\text {? }}$ an fmerican in uniform as it did to mantain saristai soldier. The manpover or the Asian 
allies would not only be chesper but ould meke it possible "to let haian fint isians".

W1itry allinces thus became the cornerstone of tre "Hex Look" stritogy. To this as adea the anti-Conanisut messiunism and "uold policiogl of secretary Dalles. Whese two In combination produced a situkion much lixe a crosias in which anybody who did not ish to join somerow jacked in moral prosity. Problems of economic and scial betternent accuired secondery place, not only because a recocupulion with them deflected from the peoje's anti-Commist zeal but their solition vould cause buggetary strins.

It was ith this policy mix that the wisenhover bimfnistrution loozed at the strategic region of Bouthern asia. Almost all the countries in trat resion had recentiy emersed srom forein aomination, ans nuturaily vienes tieir nevilyon reecon as trelr most preciolas asset. Secause of thuir so racert wherience they looked at any foreigu noves in the ars: ith misgivings. They were more concerned ith the basic probiems of gconomic, social, and politicul chanes arich hed been artificlaliy arrested diring centurise of

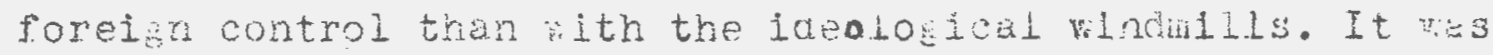
not that actors in this international sub-systen rere oblivioun of the cold war tensions, tut to them tre unly effective way to resist undesirioje extery l oressures appeared to aeperd on the satisijetory solition of trese

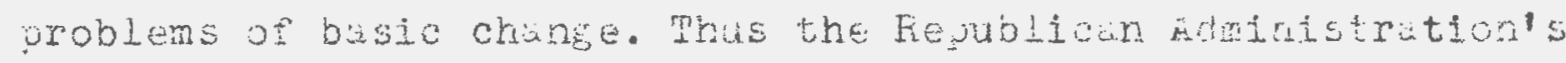


concern and the Southern hislan people's concerns $r$ a $n$ tangenjtially against each other.

The first major manifestation of the "New Look" in this region occurred in the shape of a military alliance With Paxistan. The need for arms ald to Pakistan had arisen directly from the decline of the British Emplre. Earlier Britain's India-based power had controlled the strateglc Hidale East arc encompassing the rich ollfields. The rise of Arab nationalism and Inda's refusal to let herself be used for Britain's imperial interests necessitated a new system of defense for this area. That is where Pakist n came into the picture. Britain had been anxious to persuade the United states to share Midale Gastern ofl worries. But, making no headway with the Iruman Administration, which appeared to have appreclated the political repercussions of milltary alliance with Pakistan on the national forces in Southern Asia and the lldile East, the Brit1sh quietly started working through the Pentagon. But nothing came out of thls till Mr. Dulles took over the state Department. Within months after that the question of arms sypply to Pakistan acquired nef urgency and, on May 19, 1954 Pakistan became the first J.S. milltary ally in Southern Asia.

"The "New Look" then turned to Indo-China where another imperial power, this time the tottering regime of France, was fighting a last-ditch battie against the commnist nattonal porces. It was in response to the French distress 
and the possibility of China's intervention on beliaff of the Comwuist insurgents thet hr. Dulles transated his strategy of ruclest sujoriority into a "goctrirell of instant massive retritation". He offered two atom bombs to the Franch and moved units of the soventh Fleet for a follow-ly air-strike. Simultaneously, he andowncé that the umerican actlon yould not he comined to Indo-Chine but ouli smbrec the "bases of aggresion" in tho Chinese homeina. Whon hiz kray Chief ot staff cationed inat the air-strice youls 1matidely require suport from American bround forces,

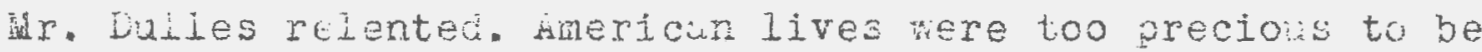
bogged don in the jungles of Indo-China so soon after tre forear experfence. Congress rould not countenane this. The wole thing would be too expensive und preposterous. The British, who had cilled a conference on Inco-Chine, foulc not go alon anci alow their efforts to be still-born. Thus checkmted, wecretary bulies fell back on the second-rate stratesy of a "posture of strength". Throwh caiculatec lean he kept us the "ceterrace" of sone contemplated Anerican action if Genevi aia rot prouluce what, Mr. Eistrinover had said, "wo could at least celi a moabs vivendi". But Dulles moxd not sit kith the hated Crinese Communists at the same conference tuble. Hru vhon the

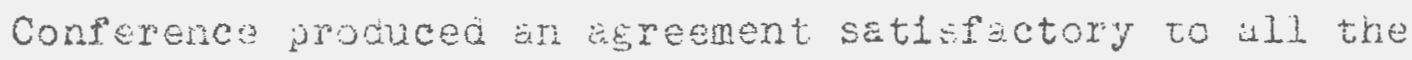
yrties concerned, he felt elmost ceserted aro would not Let America be a signitory to the "handing over" of i 
territory to Commuism.

Throughont the Gerevi Conference lur. Dulies maintained trie secona threat of collective action ln Indo-China. We had in fact alreacy invited the militiry representiativas inom a fev countries for consultations. After the Genevi accors vere signed he insisted that a estern iritiatea coliective defense shoula be organisec to underwrite them. Hurieci favitations fiere issuea to whover wated to Jaln. Three countries from the reion and five outsiaes met in uabile in

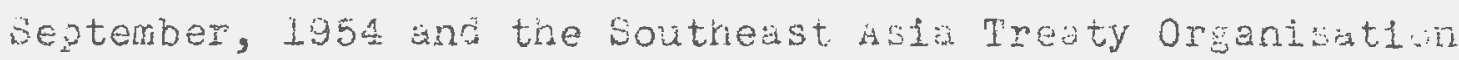
came into beinë.

This organisstion, despite Dulles' tough talk in tile pracedilu months, rovew to be tre most ineffective collective defense unatratis ever prouced by such ponernd backers. Wio wonder, bato has been aubbed as a "misoegotter baper tiger", "militarity hollow", ard"politicaliy pericious".

In their indiscriminate seajoh for allies the Duldesian ircongruities of "more security at less cost" attractea disparate bed-bellons in wouthern fisia who shoved Ittle agreament ith the American concern about Communsu. paristan wis openly suying, even before the sisning of tre allince sgreerents ith the United utstes, that its oniy alw ins to strengthen itself ustrist its neishoors: Incid and hfohasstan; India, In particular. Thijiand has been sinilarly more concerned with Cambodis and Burma than with Comunist Chind, and at one time its ambassador in hasilngton 
wert so far as to egute its nembership of seato with its membership o* the Units Nations. While none of these Southern sian allies has common porders litr either Conminist Chins or the Soviet Union, the effect of hmerican tie-uo with them has been to drive their neighbors (who do have common borders ith the Commist states) to sess ar uncerstanaing with the "New Look's" enemies. The rise of Commist influence in Afüaristan, Cambodia, Burma ara Indonesia, and the birth of the Afro-sian trend towar a more issertive incependence both from the vest and the East have been tracea bacs to the intrusion of inerican arms in southern isia.

while the alitary value of these allies to $t h e$ United States is cuestiorable, the political cost has been tremendons. By wilfuily ignoring the forces of resurgent netionalisn in this area aro by offering purely allitiry solitions to the area's basicaily social and economic problems the United Stutes sacceeded only in one respect: i.e., in deflecting aprehensions from Comanisu to hersulf. 
A. Source haterials

Cole, HLlen B., st. a. Conflict in Indo-Chiri und Int rnational Fepercussiors: A Documentiry History, $1945-55$. Nen Yorn: Corneil University Press, 1356.

Curl, pet r V. (ed.), Documents on Americar Foreigr Felativis, 1353 and 1954. (Prepred for the Council on Forein helitions). New York: fiarper \& Brothers, 135 and 135.

Foreigr Aspects of U.E. National Security. Conference Feport and Prooeedings. Wisnington: Conittee for Internetion Growth, 1958.

Nenra, Jánarlal, Indials Foreign Policy. Selected seeches in parliment: I. 1953-57 ano, II. September, 1343-A UIi, 1961. Delhi: Publictions Division, Goveraibt of Iriaia, 1958 and 1961 .

- Miliary Allizess. Excerots Fror Speeches in PanIiament, 1954-56. Nev Delhi: Lok Sanna Eecret riat, lo57.

Pisistan Chronoloside Jure, 1947-June, 195e. Suraci: Goverrment of Pakistan, 1952 .

Ten Years of Pexistan, 1947-1957. Liseci: Uovernont of ?uxistan, 1957 .

Southeset disia Collective Lefense Treaty: Hearins Before

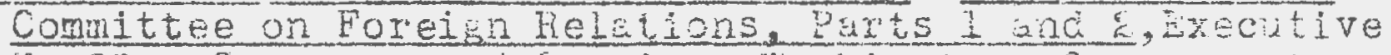
I, Bura Congress, a Sessior. Washington, Governant Printing office, 1354 (Part I) und 1955 (Part $\epsilon)$.

- Report of the Comittee on Foreiga Relutions on Executive 1,8 a Congless, ad sessior. Rsirintun: Goveriment Printing office, 1955.

Southeast Asia Ireaty Organisation, fnniai Reports. Bangiror: Seato leadcuarters, annual.

U. S. Congressional Fecoras. T6th to 8zrd Conyress.

U. D. Depertment of state, imericar Foreist Policy, 1950-55, Basic Documents, Vols. I and II, Publicction 6446. hasington: Goveriment printing of lee, $135 \%$ Billetir, Vols. XXY XXXV. 
B. Biographies ano hemoirs

Eden, ir introny, Full Circie (ulemoirs). Bozton: horinton Miffin Co., 1060 .

Lisonower, Lnisht D., Peuce ith Justice, (Selected Adaresses). New York: Columia University press, 1361.

Woold-hane, Kichard, John Foster Dulles: i Feaprisal. Nev York: Appiton-Centiry-Crofts, 196 .

Fughes, Jonn, The Ordeat of Poier: A Political inemoly of the isenhover Yesrs. New Yors: Atheneun, 1965.

Truntan, farry S., inemoirs (I): Years of Decision. Garden City: Loubleday \&o., 1955.

, (II): years of Irial and Hooe. Ibid, 1356.

Milioughby, Charles A., end Chamberlin, John, Mac Arther: 1341-1351. Nev: York: HeGras-lill Book Co., 1954.

C. General Worcs

Aaler, Seifg, The Isoletionist Imoulse: Its Itentioth Cephtiary Reaction. New York: Collier Books, 1961.

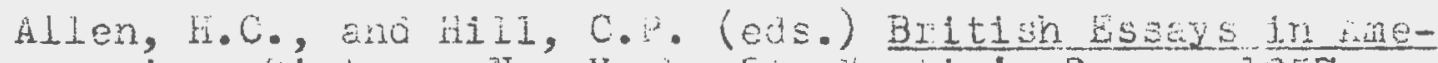
rican History. Hew York: St. 站artin's PIess, 1957.

Beil, Coral, Survey or Interrational affairs, 1954. Bov Yors: Oxforo Univertity Prese, 1957.

Boviles, Chester, hmbassador's Report. Nen York: Harper \& Brothers, 1954 .

Brown, V. Worman, The United States and Indid and pusistan: Cambridge, dass: harvard Urivereity Press, 1952.

Campell, Jon $c$, Deferse of the midie suct. Pubilined for the Council on Foreign Felations. Wev york: Harper \&. Brotress, 1958.

Cohen, Bernard C., The Political Process ana Poreins Policy: The Minina of the Jipenese Peace Settionent. Princetur: Princeton Univer ity Press, 1957.

Conlon associates, United States Forelan Polic ir fisia, Stucy Wo.5. Prepared ander tre Direction of Comittee on Foresn Relations, U.S. Benate. Wushington: Goverwment printing office, iyel. 
Donavan, Hobert J., Eiserinoner: : The Insie Story, Nen York: Hurver se Brothers, 1356.

Drumbod, Foscoe and Coblentz, Gastun, Dued it Tre Brisk: John Foeter Lulies Comiand of Americur Pover. Guren City: Doublecíy \& Co., 1960 .

Dutt, Vijye Prasash, Indid' Foxelor Polley ith upecial Feference to dsia ano tre Pacifie (bimsograhed). Prepareu for tile tieventh Conference of the Institite or Pucific felations. Nev le Lhi; Iroian Council of Vorla Hiairs, 1050.

Fifield, Russal H., The Eiplomicy of Boitheast esia: 13451356. New York: Harper \& Brothers, 13F.

Graebner, worman A, The Wow Isolacionisin: A Gtyay in Politics and Foreien ?olicy since 1950. New York: Tomla
Press Co., Lo56.

Hairison, Selig S. (ec.) Irujo and the United St tes tev Yorx: Hacmillian Co., litbl.

Jorian, Jr., thes A., Foreibn fid an the Lefense of Southesit Asia. New Yorh: Frederick A. Praejer, 196\%.

wassali, Charles B., The Limits of Foreisn Policy. Nev York: Henry Holt \& Co., 1354.

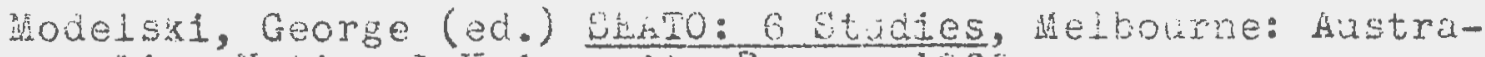
Iian National University Press, 136\%.

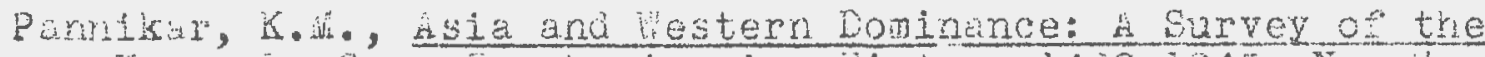

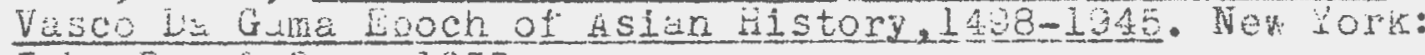
John Day \& Co., $195 z$.

Koyal Inst1tute of International iffairs, Coliective Deferse in South East Asia. Report of ¿ Stidy Group. London: H.I.I.A., 1356.

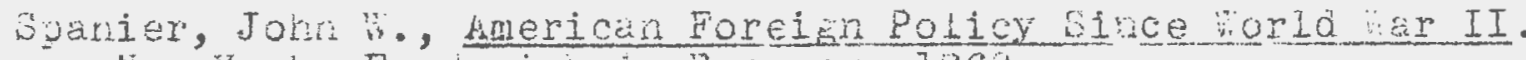
New Yorz: Frederick A. Praeger, 1960.

Wolfers, Arnold A. (ed.) hIliance Policy in the Cold ar. Bestinore: John Hopirins Press, 135.

D. Axticies

Acheson, Dean, "ine Parties and Foreign lolicy", Litists CCXI (December, 1955).

Arastrans, John?., "qne fnigmi of benctor isft ano poreign Policy", Rview of Polities, XVII (April, las5). 
iscoli, lax, Horton, Philif and Wartenbarer, Charles, "The China Lobby", Feporter, IV (4pril 15 ard 3,135$)$.

Hhaed, aziz, "smeriosn Hliences ith Asian Countries",

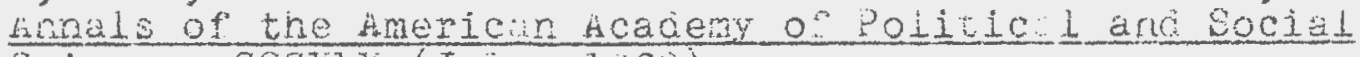
Scierce, $\operatorname{Cccxdx}(J u i y, 1960)$.

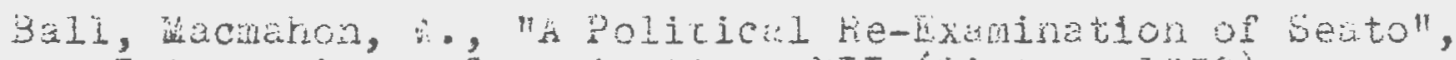

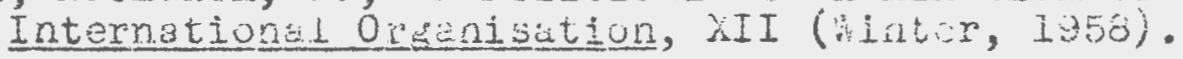

Bones, Chester, "Less Seci1ty, Less Urity", Componeal, is (kil wo, 1954).

Breibanti, ralon, "The Southeast fisia collective Jefease Ireaty", Pecitic iffairs, XXX (Lecenter, 195\%).

Dulles, Jonn Foster, "h Posicy of Boldness", Life, XXXI (itay $1: 1056)$.

"Maximu Deterrence at Bearabe Cost", Adaress is

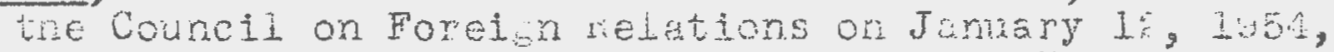
reproduce incer tre title "Bvolution oi For ín Polic" ir U. We Wertment of Stute Bulietir, XXX, (J unitry 5,54$)$.

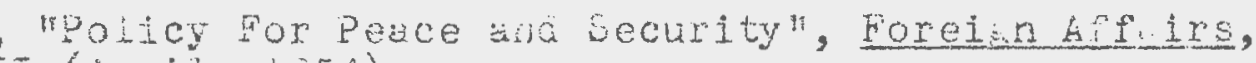
XXXII (

"Further Explanation" Text of Pre:s Conivence or Hareh 10, 1354, rejroduced in Cirrert History, XXVI (niay, $\left.105 k_{2}\right)$.

- "Challenge hro fiesponse in Unitec states Policy", Foreigr Affsirs, XXXVI (0ctober, 1357).

Harrisoi, weilg S., "India, Panfotan and U. : : I. Case Hitory of a ilistane, II. Cost of a Mistake, III. Uncioina $a$ 路istare", The lep Republic, CXuI (Augist lu a d is and September 7, 1956 ).

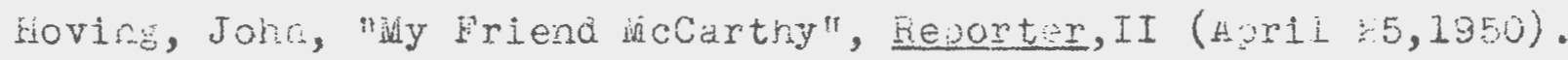

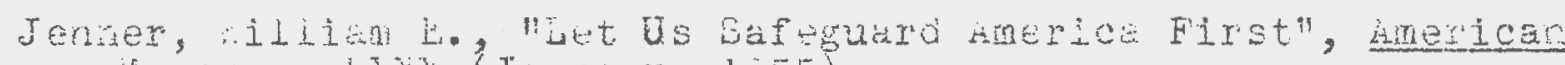

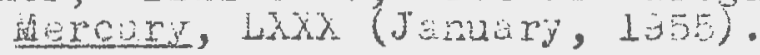

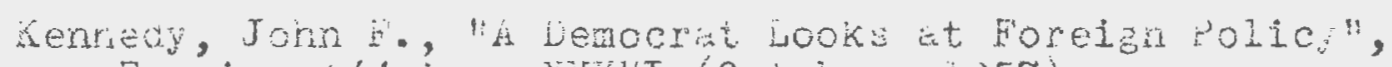
Foreis: 16 birs, XXXV (Octob $r$, 1057).

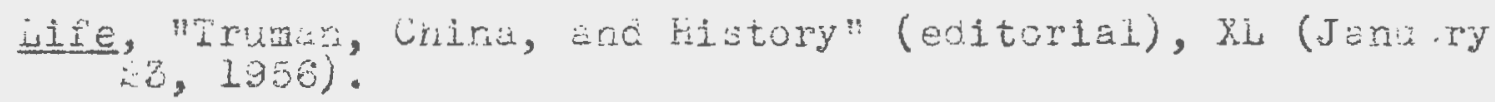

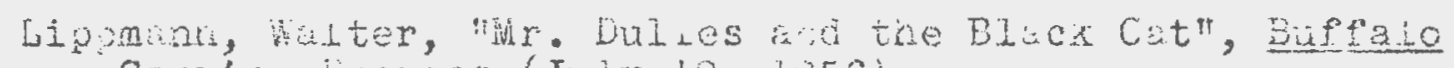
Courfer-Express, (July 19, L956). 


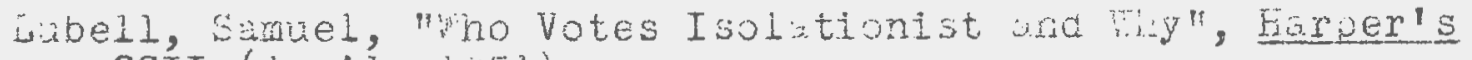
CCII (Avil, 1 i5l).

Worgentrak, Huns J., "The Immaturity of Our Azian Policy:

I. Icealofical indmils, II. Hilibury Illusions, and

III. The Fristritions of Foreign isin", Tre new Hejublic, CXXXIV (nerch l:, ly, und 66 , 1958).

Pursone, Tulcott, "incCartryisn and heriear bocial Texsions: A Sociolosist's Viev", Yale lievien, XuIV (Ueceraer,1954).

bonlesinger, hrthur id., "The Nen. Isolotionism", Atientic CLXXYIX (MaY, 1952).

Bchumann, Frederick li, "Formalas for Foreign Policy", Nution CiXXX (Nireh Li, 1955).

"Senator Knolind Ariswers Trenty Guestions on Forei palley", American Hercury, LXXXI (October, 1y5s).

Shepisg, Jumes, "Fow Dulles favered War", Life XL (Junury $16,1956)$.

smuckler, kalph H., "The Fesion of Isolationism", 4mencan Political Science revier, Xist (Juna, 1953).

Stanton, Fuin F., "Commist Pressares in Thaldna", Current IiIstory, XXXVIII (Feordary, 1960).

"Wite Man's Burden", Birroa's, XXXV (October 10, 1955).

Bhite, viliam S., "Whut BIl Kronland Stancs For", the Nov Republic, CXXXIV (Febrisry 7 , 1950).

Wiliarns, Davia C., "Does america He a Policy?", Tuentieth Century, CLVI (August, 1954).

filson, Cherles i., "Wilson Explains Prostam to Gain maxi-

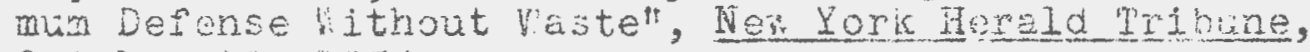
October 1:, $135 \%$. 